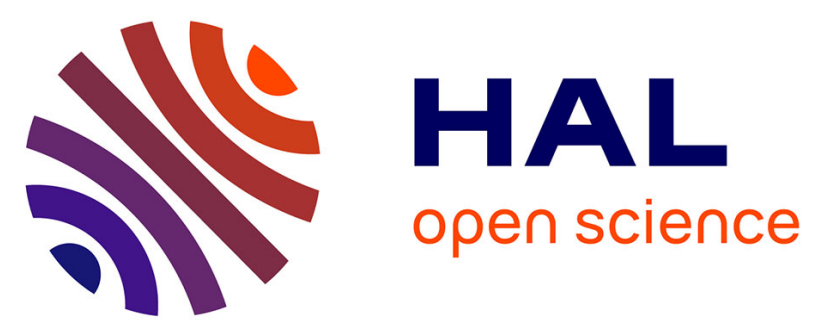

\title{
Tacrolimus versus cyclosporine as primary immunosuppression after heart transplantation: systematic review with meta-analyses and trial sequential analyses of randomised trials
}

Luit Penninga, Christian H. Møller, Finn Gustafsson, Daniel A. Steinbrüchel, Christian Gluud

\section{To cite this version:}

Luit Penninga, Christian H. Møller, Finn Gustafsson, Daniel A. Steinbrüchel, Christian Gluud. Tacrolimus versus cyclosporine as primary immunosuppression after heart transplantation: systematic review with meta-analyses and trial sequential analyses of randomised trials. European Journal of Clinical Pharmacology, 2010, 66 (12), pp.1177-1187. 10.1007/s00228-010-0902-6 . hal-00627922

\section{HAL Id: hal-00627922 \\ https://hal.science/hal-00627922}

Submitted on 30 Sep 2011

HAL is a multi-disciplinary open access archive for the deposit and dissemination of scientific research documents, whether they are published or not. The documents may come from teaching and research institutions in France or abroad, or from public or private research centers.
L'archive ouverte pluridisciplinaire HAL, est destinée au dépôt et à la diffusion de documents scientifiques de niveau recherche, publiés ou non, émanant des établissements d'enseignement et de recherche français ou étrangers, des laboratoires publics ou privés. 


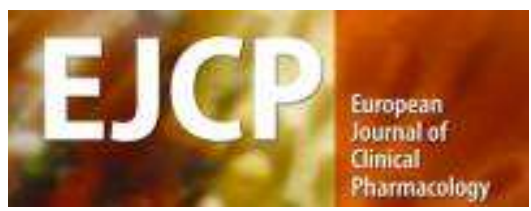

\section{Tacrolimus versus cyclosporine as primary immunosuppression after heart transplantation: systematic review with meta-analyses and trial sequential analyses of randomized trials}

\begin{tabular}{|r|l|}
\hline Journal: & European Journal of Clinical Pharmacology \\
\hline Manuscript ID: & EJCP-2010-0239.R1 \\
\hline Type of submission: & Review Article \\
\hline Date Submitted by the & 30-Aug-2010 \\
\hline Complete List of Authors: & $\begin{array}{l}\text { Penninga, Luit; Rigshospitalet, Copenhagen University Hospital, } \\
\text { 3344, Copenhagen Trial Unit; Rigshospitalet, CTX, Surgery and } \\
\text { Transplantation } \\
\text { Møller, Christian; Rigshospitalet, Copenhagen University Hospital, } \\
\text { Cardiothoracic Surgery, RT 2152 } \\
\text { Gustafsson, Finn; Rigshospitalet, Copenhagen University Hospital, } \\
\text { Cardiology, B2142 } \\
\text { Steinbrüchel, Daniel; Rigshospitalet, Copenhagen University } \\
\text { Hospital, Cardiothoracic Surgery, RT 2152 } \\
\text { Gluud, Christian; Rigshospitalet, Copenhagen University Hospital, } \\
\text { 3344, Copenhagen Trial Unit, Centre for Clinical Intervention } \\
\text { Research, Cochrane Hepato-biliary Group }\end{array}$ \\
\hline
\end{tabular}


1

2

3

4

5

6

7

8

9

10

11

12

13

14

15

Tacrolimus versus cyclosporine as primary immunosuppression after heart transplantation:

Systematic review with meta-analyses and trial sequential analyses of randomized trials

Luit Penninga ${ }^{1,2}$, Christian H Møller ${ }^{1,3}$, Finn Gustafsson ${ }^{4}$, Daniel A Steinbrüchel ${ }^{3}$, Christian Gluud $^{1}$

${ }^{1}$ Copenhagen Trial Unit, Centre for Clinical Intervention Research, Cochrane Hepato-biliary

Group, Department 3344, Rigshospitalet, Copenhagen University Hospital, Copenhagen, Denmark

${ }^{2}$ Department of Surgery and Transplantation C2122, Rigshospitalet, Copenhagen University

Hospital, Copenhagen, Denmark

${ }^{3}$ Department of Cardiothoracic Surgery RT 2152, Rigshospitalet, Copenhagen University Hospital,

Dept RT-2152, Copenhagen, Denmark

${ }^{4}$ Department of Cardiology, B2142, Rigshospitalet, Copenhagen University Hospital, Copenhagen,

Denmark

Corresponding Author: Luit Penninga, MD

E-mail: $\underline{\text { LP@ctu.rh.dk }}$

Tel +453545 7113/ +4535457154

Fax +4535457101 


\section{Abstract}

Purpose We conducted a systematic review of randomized trials to compare benefits and harms of tacrolimus versus cyclosporine as primary immunosuppression after heart transplantation. Methods and results We searched electronic databases and bibliographies until April 2010. Our review followed the Cochrane and PRISMA guidelines. The meta-analysis included 10 randomized trials with 952 patients. Tacrolimus was significantly superior to cyclosporine (both formula combined) regarding hypertension (relative risk (RR) 0.8 ; 95\% confidence interval (CI) 0.69-0.93, $\mathrm{p}=0.003)$ ], hyperlipidaemia (RR 0.57; 95\% CI 0.44-0.74, $\mathrm{p}<0.0001$ ), hirsutism (RR $0.1795 \% \mathrm{CI}$ 0.04-0.62, $\mathrm{p}=0.008$ ), and gingival hyperplasia ( $\mathrm{RR} 0.0795 \% \mathrm{CI} 0.01-0.37, \mathrm{p}=0.002$ ). No significant differences between the two calcineurin inhibitors were found regarding acute rejections causing hemodynamic instability, diabetes, renal dysfunction, infection, malignancy, or neurotoxicity. Tacrolimus was significantly superior to microemulsion cyclosporine regarding mortality (RR 0.64 ; 95\% CI 0.42-0.96, $\mathrm{p}=0.03$ ), acute severe biopsy-proven rejection (RR 0.71; 95\% CI 0.560.90, $\mathrm{p}=0.004$ ), hyperlipidaemia (RR 0.57; 95\% CI 0.41-0.79, $\mathrm{p}=0.0009$ ), hirsutism (RR $0.1795 \%$ CI 0.04-0.62, $\mathrm{p}=0.008$ ), and gingival hyperplasia (RR 0.07; 95\%CI 0.01-0.37, $\mathrm{p}=0.002)$. Tacrolimus was significantly superior to oil-based cyclosporine regarding hypertension (RR 0.66; 95\% CI 0.54$0.80, \mathrm{p}<0.0001)$ and hyperlipidaemia (RR 0.57; 95\% CI 0.38-0.87, $\mathrm{p}=0.009)$.

Conclusion Tacrolimus seems to be superior to cyclosporine in heart transplanted patients regarding hypertension, hyperlipidaemia, gingival hyperplasia and hirsutism. In addition, tacrolimus seems to be superior to microemulsion cyclosporine in heart transplanted patients regarding a number of outcomes including death. More trials with low risk of bias are needed to determine if the results of the present meta-analysis can be confirmed. 
Keywords Heart transplantation ·Cyclosporine · Tacrolimus ·Calcineurin inhibitors · Meta-analysis 


\section{Introduction}

The therapeutic success of heart transplantation has been largely attributable to the development of effective and balanced immunosuppressive treatment regimens [1,2]. Especially the calcineurin inhibitors were essential in reducing acute rejection and improving early survival [2]. Two

Field Code Changed calcineurin inhibitors, cyclosporine and tacrolimus, are currently used as primary immunosuppression in heart transplant recipients [1,2].

Cyclosporine was discovered in 1971, and in 1983 the drug was approved for prevention or treatment of transplant rejection [3]. To overcome the intra-individual and inter-individual differences in absorption and biovailability of the original oil-based formulation of cyclosporine (Sandimmune $\left.{ }^{\circledR}\right)$, a micro-emulsion formula of cyclosporine (Neoral®) was introduced in the 1990s [3].

Field Code Changed

Tacrolimus (Prograf ${ }^{\circledR}$ ) was discovered in the early 1980s and from 1989 used for the prevention of liver transplant rejection $[3,4]$. Since then, its use expanded rapidly into transplantation of other organs [3]. Both cyclosporine and tacrolimus inhibit the action of the phosphatase calcineurin.

Calcineurin regulates the transport of NFAT (nuclear factor of activated T-cells, which is a transcription factor regulating lymphokine gene transcription. Cyclosporine and tacrolimus exert their cellular effects on the action of calcineurin through different cytoplasmatic receptors, as

cyclosporine binds to cyclophilins and tacrolimus binds to FK-binding proteins [5]. Differences in adverse effects, safety and tolerability between, cyclosporine and tacrolimus have been observed, but the toxicodynamic molecular mechanism of both drugs are still largely unknown and the involvement of calcineurin inhibition in calcineurin inhibitir toxicity is unclear [6]. 
To date several randomized trials have compared tacrolimus vs. cyclosporine, but results have been inconsistent and optimal immunosuppressive maintenance therapy continues to be debated $[5,6]$.

We conducted this systematic review to compare benefits and harms of tacrolimus vs. cyclosporine in heart transplant recipients.

\section{Methods}

\section{Trial selection and characteristics}

Our review followed the Cochrane Collaboration [7] and PRISMA guidelines [8]. A protocol was developed (www.ctu.dk/protocols) and we included all randomized trials comparing tacrolimus versus cyclosporine after first-time isolated heart-transplantation. We required that all included patients received the same additional immunosuppressive therapy within each trial. Our preselected outcome measures were mortality, acute severe rejection defined as cardiac biopsies of grade $3 \mathrm{~A}$ or higher according to the classification of the ISHLT (equivalent to grade H2R in the recently revised classification) [9]; acute rejection causing haemodynamic instability; Cytomegalovirus (CMV) infection; basocellular skin cancer; all malignancies excluding basocellular skin cancer; arterial hypertension; diabetes mellitus; hyperlipidaemia; total serum cholesterol; renal failure requiring haemodialysis; serum creatinine levels; neurotoxicity; hirsutism; and gingival hyperplasia. Our preselected subgroup analyses included 1) low-risk bias compared to high-risk bias trials 2) microemulsion cyclosporine compared to oil-based cyclosporine formulation 3) total population (adult and paediatric studies) compared to adult studies only (www.ctu.dk/protocols).

\section{Search strategy}

We searched The Cochrane Central Register of Controlled Clinical Trials (CENTRAL),

MEDLINE, EMBASE, and the Science Citation Index Expanded (to April 2010) [10]. Search terms 
were (c*closporin* or CyA or Neoral* or Sandimmun*) combined with (tacrolimus or FK506 or FK 506 or Prograf) and ‘heart transplantation' [MESH term] and (random* or blind* or placebo* or meta-analysis).

We scanned bibliographies of relevant articles for additional trials. We had no restrictions to
blinding, language, or publication status.

Data extraction and quality assessment

Three authors independently assessed trial eligibility (LP, CHM and FG). We assessed the impact of bias risk by evaluating the trials with respect to generation of the allocation sequence, allocation concealment, blinding, and reporting of incomplete outcome data [11]. Generation of the allocation

Field Code Changed sequence was considered adequate when generated by a computer, random-number table, shuffling of cards, or something similar. Allocation concealment was considered adequate when allocation of patients involved a central independent unit, such as an on-site locked computer, sealed envelopes or something similar. Blinding was adequate if the trial was described as double-blind and the method of blinding involved identical active drugs. Post-randomization exclusion of patients was registered. When possible we converted per-protocol to intention-to-treat-analysis. Bias risk was assessed without blinding by 3 authors [11].

\section{Quantitative data synthesis}

We used Cochrane Collaboration Software (RevMan 5.0.22). Data were analysed with both fixedeffect and random-effects models. In case of discrepancy regarding significance between the two models both results were reported. Otherwise, only results from the random-effects model were reported. Data were presented as relative risk (RR) with values less than 1.0 favouring tacrolimus, 
and with $95 \%$ confidence intervals (CI). Heterogeneity was assessed with $\mathrm{I}^{2}$, which describes the percentage of the variability in effect estimates that is due to heterogeneity rather than sampling error (chance). $\mathrm{I}^{2}$ lies between $0 \%$ (no heterogeneity) and 100\% (maximal heterogeneity) [12]. Test of interaction was performed to evaluate the difference between the 2 estimates [13].

Field Code Changed errors because of sparse data or repetitive testing on accumulating data [14]. To minimize random errors we calculated the required information size (i.e., the number of participants needed in a metaanalysis to detect or reject a certain intervention effect) [14]. Information size calculation also

Field Code Changed accounted for the diversity present in the meta-analysis. In our meta-analysis, information size was based on the assumption of a plausible RR reduction of $20 \%$ [14]. The underlying assumption of trial sequential analysis is that significance testing may be performed each time a new trial is added to the meta-analysis. We added the trials according to the year of publication. On the basis of the required information size and risk for type I and type II errors trial sequential monitoring boundaries were constructed [14]. These boundaries will determine the statistical inference one may draw regarding the cumulative meta-analysis that has not reached the required information size. If a trial sequential monitoring boundary is crossed before the required information size is reached in a cumulative meta-analysis, firm evidence may have been established and further trials are superfluous. On the other hand, if the boundaries are not surpassed, it is most probably necessary to continue doing trials in order to detect or reject a certain intervention effect. We used as defaults a type I error of $5 \%$, type II error of $20 \%$, and adjusted the information size for diversity unless otherwise stated [14]. 


\section{Results}

Figure 1 depicts the results of the search strategy. Database searches identified 450 references.

Exclusion of duplicates and irrelevant references left 11 randomized trials published in 25

publications [15-39]. One trial could not be included in the meta-analysis as none of the outcome

measures were addressed [29]. We confirmed with the authors that all patients only participated

once in the trials $[28,30]$

Field Code Changed

Field Code Changed

Field Code Changed

The meta-analyses involved 10 trials with a total of 952 patients (table 1): 486 patients were randomized to tacrolimus and 466 patients to cyclosporine [15,16,19,20,24-28,30]). Three trials with 192 patients compared tacrolimus with the old formula oil-based cyclosporine [24,26,27] and Field Code Changed

Field Code Changed seven trials with 760 patients compared tacrolimus with the new formula microemulsion cyclosporine $[15,16,19,20,25,28,30]$.

Field Code Changed

Field Code Changed

In 8 trials the population consisted of adult patients [15,19,20,24,26-28,30], while in 1 trial the population consisted of a combination of adult and paediatric patients [16], and in 1 trial only

Field Code Changed

Field Code Changed paediatric patients were included [25].

Field Code Changed receiving tacrolimus and mycophenolate mofetil, and one receiving tacrolimus and sirolimus [19]. We therefore excluded the latter group of our analyses. Immunosuppressive treatment varied within trials. All patients were treated with steroids. As antiproliferative agent azathioprine ( 7 trials [15,16,24-28]) or mycophenolate mofetil (3 trials [19,20,30]) was used. Induction therapy was used for all patients in 4 trials [15,25,26,28], for some of the patients in 3 trials [19,24,27], and for none

Field Code Changed Field Code Changed Field Code Changed Field Code Changed 
in 3 trials $[16,20,30]$. In case induction therapy was used, either anti-thymocyte globulin (ATG) or muromonab-CD3 (OKT3®) was administered $[15,25,26,28]$. Patients were followed from 6 months to 5 years.

Trial methodology was inadequately reported in the majority of trials (table 2). All trials were considered trials with high risk of bias.

\section{Mortality}

Ten trials reported on mortality, and overall no significant difference in mortality was found between tacrolimus and cyclosporine (relative risk (RR) $0.78 ; 95 \% \mathrm{CI} 0.54-1.13, \mathrm{p}=0.19$ ). Tacrolimus was significantly superior to microemulsion cyclosporine (RR 0.64; 95\% CI 0.42-0.96, $\mathrm{p}=0.03$ ). No significant difference in mortality between tacrolimus and oil-based cyclosporine was found (RR 1.79; 95\% CI 0.77-4.15, $\mathrm{p}=0.17$ ). Test of interaction showed significant difference in intervention effect on mortality between the oil-based and microemulsion cyclosporine formulas $(\mathrm{p}=0.04)$.

The significant difference in mortality between tacrolimus and microemulsion cyclosporine, however, disappeared when the studies including paediatric patients were excluded (RR 0.66; 95\% CI $0.40-1.09, \mathrm{p}=0.10$ ). Test of interaction showed no significant differences in mortality between the paediatric and adult cyclosporine subgroups ( $\mathrm{p}=0.89$ ), This suggests that the lack of significance caused by withdrawing paediatric studies was solely caused by reducing the number of patients in the groups.

Acute rejection 
No significant difference in grade $3 \mathrm{~A}$ or higher rejection was found between tacrolimus and (both formula combined) cyclosporine (RR 0.86 ; 95\% CI 0.62-1.20, $\mathrm{p}=0.38$ ). However, tacrolimus was associated with a significant reduction in Grade 3 A or higher rejection compared to microemulsion cyclosporine (RR 0.71; 95\% CI 0.56-0.90, p=0.004).

Rejection causing haemodynamic instability was reported in 5 trials comparing tacrolimus versus microemulsion cyclosporine and no significant difference was found (RR 0.96; 95\% CI 0.34-1.38, $\mathrm{p}=0.29)$.

\section{Infections}

Infections were analysed as number of patients who experienced at least one episode of infection. No significant difference in proportion of patients with infection was found between tacrolimus and cyclosporine (RR 1.01; 95\% CI 0.84-1.21, p=0.91). Neither was any significant difference found when subgroup analysis for the microemulsion and oil-based cyclosporine was applied. In addition 2 trials compared number of patients with CMV infection for tacrolimus versus microemulsion cyclosporine, and no significant difference was found (RR 1.03; 95\% CI 0.75-1.42, $\mathrm{p}=0.85$ ).

\section{Malignancies}

According to our protocol we analysed malignancies as basocellular skin cancer and all other cancers excluding basocellular skin cancer. Three trials found no significant difference between tacrolimus versus microemulsion cyclosporine on basocellular skin cancer (RR 1.20; 95\% CI 0.294.93, $\mathrm{p}=0.80$ ). Four trials reported on other cancers and found no significant difference between tacrolimus and cyclosporine (RR 0.57; 95\% CI 0.20-1.63, $\mathrm{p}=0.85)$. Nor did we find any significant difference when subgroup analysis for the microemulsion and oil-based cyclosporine was applied. 


\section{Hypertension}

Eight trials found significantly less hypertension in patients treated with tacrolimus compared with cyclosporine (RR 0.80; 95\% CI 0.69-0.93, $\mathrm{p}=0.003$ ). In addition subgroup analysis showed that hypertension was less common for tacrolimus compared with oil-based cyclosporine (RR 0.66; 95\% CI 0.54-0.80, p $<0.0001)$. An insignificant trend was seen towards less hypertension for tacrolimus compared with microemulsion cyclosporine (RR $0.88 ; 95 \%$ CI $0.77-1.01, \mathrm{p}=0.07$ ). The difference was significant when a fixed-effect model was applied (RR 0.86; 95\% CI 0.78-0.95, p=0.003).

\section{Hyperlipidaemia}

Four trials reported on the number of patients treated pharmacologically for hyperlipidaemia and 5 trials reported on total serum cholesterol. Significantly less patients treated with tacrolimus received treatment for hyperlipidaemia compared with cyclosporine (RR 0.57 ; $95 \%$ CI $0.44-0.74, \mathrm{p}<0.0001$ ). This was both seen for patients treated with oil-based cyclosporine (RR 0.57; 95\% CI 0.38-0.87, $\mathrm{p}=0.009$ ) and microemulsion cyclosporine (RR $0.5795 \%$ CI 0.41-0.79, $\mathrm{p}=0.0009)$. In addition, we found that tacrolimus significantly lowers total cholesterol compared with cyclosporine (mean difference $0.4 \mathrm{mmol} / \mathrm{L} ; 95 \% \mathrm{CI}-0.66$ to $-0.22 \mathrm{mmol} / \mathrm{L}, \mathrm{p}<0.0001$ ). This was both seen for the oil-based $(\mathrm{p}=0.005)$ as for the microemulsion $(\mathrm{p}=0.002)$ subgroups, and the effect was seen even though in some of the trials more patients in the cyclosporine group were on cholesterol lowering therapy.

\section{Diabetes}

Eight trials reported on diabetes. An insignificant trend towards more diabetes was seen in tacrolimus compared with cyclosporine ( $\mathrm{RR} 1.35 ; 95 \%$ CI $0.93-1.94, \mathrm{p}=0.11$ ). No significant difference was seen for subgroup analyses on oil-based cyclosporine (RR 1.07, 95\% CI 0.40-2.90, 
$\mathrm{p}=0.89$ ) and microemulsion cyclosporine (RR $1.50,95 \%$ CI $0.90-2.50, \mathrm{p}=0.12)$. When the fixedeffect model was applied, we found significant differences between tacrolimus and cyclosporine (RR 1.24; 95\% CI 1.02-1.49, p=0.03) and tacrolimus and microemulsion cyclosporine (RR 1.25 95\% CI 1.03-1.51, $\mathrm{p}=0.02)$.

\section{Renal function}

No significant difference between tacrolimus and cyclosporine was seen concerning renal failure requiring haemodialysis ( $R R$ 1.45; 95\% CI 0.50-4.26, $\mathrm{p}=0.49$ ). In addition no significant difference was seen for subgroup analyses on oil-based cyclosporine and microemulsion cyclosporine. Serum creatinine at end of the trials $(\mathrm{n}=6)$ was $8 \mu \mathrm{mol} / \mathrm{L}$ lower in patients treated with tacrolimus compared with cyclosporine, however, this difference was not significant (95\% CI -18.3 to -1.7 $\mu \mathrm{mol} / \mathrm{L}, \mathrm{p}=0.11$ ). Nor was any significant difference seen in serum creatinine for subgroup analyses on oil-based cyclosporine and microemulsion cyclosporine.

\section{Chronic allograft vasculopathy}

Five trials reported on chronic allograft vasculopathy, and no significant difference was found for tacrolimus compared with cyclosporine (RR 1.22; 95\% CI 0.72-2.05, p=0.46). Nor was any difference found for subgroup analysis on oil-based cyclosporine and microemulsion cyclosporine.

\section{Hirsutism and gingival hyperplasia}

Hirsutism was reported in 2 trials and was significantly less frequent seen in patients treated with tacrolimus than microemulsion cyclosporine (RR 0.17; 95\% CI 0.04-0.62, p=0.008). Gingival hyperplasia was reported in three trials and was significantly less frequent seen in patients treated with tacrolimus than with microemulsion cyclosporine (RR 0.07; 95\% CI 0.01-0.37, $\mathrm{p}=0.002$ ). 


\section{Neurotoxicity}

Neurotoxicity was reported in 5 trials and was analysed as number of patients who experienced at least one neurotoxic reaction or stroke. No significant difference was observed (RR 1.31; $95 \%$ CI 0.58-3.00, $\mathrm{p}=0.50$ ). Nor was any significant difference detected when subgroup analysis for the microemulsion and oil-based cyclosporine was applied.

\section{Adult patients}

We performed subgroup analysis for only adult patients by excluding the 2 trials including only or partly paediatric patients $[16,25]$. We did not find any differences for any of the outcome measures except for the difference in mortality, which was described above.

Trial sequential analysis

Trial sequential analysis was performed for the statistical significant differences in mortality seen for both the tacrolimus vs. oil-based cyclosporine group as well for the tacrolimus versus microemulsion cyclosporine group. In none of the analyses was the required information size obtained and none of the trials sequential monitoring boundaries were broken by the cumulative Zcurve.

\section{Discussion}

\section{Principal findings}

Our systematic review has generated a number of important findings. Tacrolimus seems to be significantly superior to both types of cyclosporine as regards hypertension, hyperlipidaemia, 
hirsutism, and gingival hyperplasia. Furthermore tacrolimus seems to be significantly superior to microemulsion cyclosporine regarding mortality and acute severe biopsy proven rejection.

\section{Strengths}

Our systematic review of randomized trials offers a number of advantages. We conducted our review according to a protocol following the recommendations of the Cochrane Collaboration [7] and published our protocol before the conduct of the review (www.ctu.dk/protocols). We systematically searched a number of databases and reference lists for randomized trials, which should have reduced selection bias to a minimum [40]. We selected trials and extracted data in triplicate. We conducted sensitivity analyses using different models. We considered risk of systematic errors ('bias'), risks of random errors ('play of chance'), as well as risk of design errors (e.g., type of cyclosporine) [40]. We reported our findings in accordance with PRISMA [8].

\section{Limitations}

This systematic review also encompasses some limitations. The quality and quantity of available evidence limit our findings and interpretations. All trials had high risk of bias [40]. Moreover, only few patients with relatively few outcomes were included in the trials. Hence, risks of random errors are potential explanations of our findings as suggested by our trial sequential analyses on mortality. In addition, patients included in randomized trials may not be representative of the general patient population. For instance most trials included in the current review did not include patients who were bridged to transplantation with a left ventricular device. The proportion of patients bridged to transplantation with an assist device has been increasing in the general heart transplantation population and consisted of $19 \%$ in a recent analysis [1]. Moreover, in recent years heart transplant recipients have become older during the technical evolution, with currently $25 \%$ of all heart 
transplants performed in people over 60 years of age [1]. These factors could potentially influence the external validity of the included trials.

\section{Perspective}

In our meta-analysis tacrolimus was found superior to the new microemulsion cyclosporine concerning mortality in terms of risk of dying, but no significant difference between tacrolimus and the old formula oil-based cyclosporine was observed. The question arises how this difference can be explained, as microemulsion cyclosporine was introduced to overcome the differences in absorption and oral bioavailability of the original oil-based formulation of cyclosporine [2]. Microemulsion cyclosporine results in higher maximum cyclosporine concentrations than oil-based cyclosporine $\underline{\text { even when cyclosporine trough }(\mathrm{C} 0) \text { levels are similar, which might influence tolerability and }}$ toxicity. A randomized multicenter trial comparing both cyclosporine formulas found more consistent bioavailability of the microemulsion formula resulting in less severe acute rejection in patients treated with the new formula, however, no significant difference in mortality was found at 24 months follow-up in 380 patients [41].

\section{Field Code Changed}

Deleted: One would expect better or at least equal results for cyclosporine after the new formula was introduced. Our study found the contrary. II

Concerning the difference in mortality observed for the two different cyclosporine formulas in our meta-analysis, it should be noted that clinical experience with tacrolimus was more limited in the trials comparing this drug with oil-based cyclosporine compared to the trials comparing tacrolimus with microemulsion cyclosporine, and tacrolimus blood target levels were higher in the trials with oil-based cyclosporine compared to the trials with microemulsion cyclosporine [15-21,21-28,30]. However, a randomized trial comparing low and high tacrolimus doses in heart transplant recipients did not find any significant difference in mortality, but a more favourable safety profile for the patients treated with a low tacrolimus dose [42].

Field Code Changed 
Traditionally cyclosporine dosing has been based on trough cyclosporine level (C0) monitoring [43]. Cyclosporine level at 2 hours post-dose (C2) has though been found to be the best single timepoint point predictor of 0 to 4-hour abbreviated area under the absorption curve $\left(\mathrm{AUC}_{0-4}\right)$ in heart, $\underline{\text { lung, kidney and liver transplant recipients }[43,44] \text {. Clinical benefits have been shown for other }}$ solid organ recipients when $\mathrm{C} 2$ monitoring was applied compared to C0 [44]. For heart transplant $\underline{\text { recipients the picture is more unclear as one large trial did not find a correlation between } \mathrm{C} 2 \text { levels }}$ and the incidence of rejection [44]. It appears though, that in general a lower C2 level may be sufficient to prevent rejection, and with lower levels different adverse effects might be expected $[43,44]$. None of the trials in this meta-analysis applied C2 levels for therapeutic drug monitoring of cyclosporine, and we were therefore not able to analyze $\mathrm{C} 0$ compared to $\mathrm{C} 2$ monitoring in our trial.

The statistical significant difference in mortality between tacrolimus and microemulsion cyclosporine disappeared when two trials including paediatric patients were excluded. However results for the different trials were consistent and none of the trials found tacrolimus to be inferior to cyclosporine. No significant difference between adult and paediatric patients was found when test of interaction was performed. This suggests that the lack of significance caused by withdrawing paediatric studies was caused by reducing the number of patients in the groups.

Our meta-analysis found tacrolimus to be associated with less severe acute biopsy proven rejection compared with microemulsion cyclosporine. This is in line with observational data from The ISHLT showing that $19 \%$ of patients who at transplant discharge were receiving tacrolimus and mycophenolate mofetil suffered a treated rejection as compared to $27 \%$ of patients receiving cyclosporine and mycophenolate mofetil $(\mathrm{p}<0.0001)[1]$. 
3
Another meta-analysis regarding tacrolimus versus microemulsion cyclosporine has been published, and results are slightly different from our systematic review $\lfloor 45]$, This might be explained by the following: we found additional randomized trials comparing tacrolimus with microemulsion cyclosporine [30], we excluded studies which were not properly randomized [46], and we excluded study groups where there were differences in concomitant immunosuppressive medication between the tacrolimus and cyclosporine treatment groups [19]. Furthermore, we included trials comparing tacrolimus with oil-based cyclosporine [24,26,27].

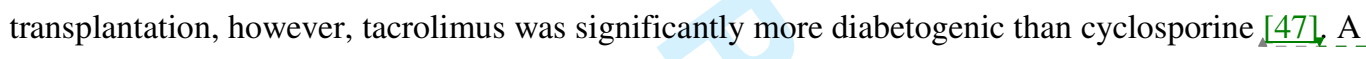
meta-analysis comparing tacrolimus versus cyclosporine in 4102 kidney transplant recipients found tacrolimus to be superior to cyclosporine in improving graft survival and preventing acute rejection after kidney transplantation, however, tacrolimus was found to increase post-transplant diabetes, neurological, and gastrointestinal adverse effects [48], The reduction in acute rejection and subgroup of heart transplant recipients where tacrolimus was compared to microemulsion cyclosporine. In contrast to kidney and liver transplant recipients we did not find a significant difference on diabetes in heart transplant recipients, however, an insignificant trend towards more diabetes in the tacrolimus group was seen.

\section{Conclusion}


Recognizing the limitations of the study due to the size and nature of the included trials, our systematic review shows that tacrolimus seems superior to cyclosporine in heart transplant recipients regarding hypertension, hyperlipidaemia, hirsutism and gingival hyperplasia. In addition, tacrolimus seems to be superior to microemulsion cyclosporine regarding mortality and acute severe biopsy-proven rejection. Given the result of our analysis it appears that an appropriately sized, randomized trial of tacrolimus versus microemulsion cyclosporine using contemporary target levels and adjunctive immunosuppression in cardiac transplantation is warranted to determine if the results of the present meta-analysis can be confirmed.

\section{Acknowledgements}

This work was supported by a grant from the Rigshospitalet Research Council to LP.

Supplementary material

Supplementary material (forrest plots of all meta-analyses and an additional table on immunosuppressive treatment strategies and drug target levels of the included studies) is available at European Journal of Clinical Pharmacology online. 
1. Taylor DO, Stehlik J, Edwards LB et al (2009) Registry of the international society for heart and lung transplantation: twenty-sixth official adult heart transplant report-2009. J.Heart Lung Transplant 28:1007-1022.

2. Valantine $\mathrm{H}(2000)$ Neoral use in the cardiac transplant recipient. Transplant Proc. 32:27S$44 \mathrm{~S}$.

3. Kapturczak MH, Meier-Kriesche HU, Kaplan B (2004) Pharmacology of calcineurin antagonists. Transplant Proc. 36:25S-32S.

4. Starzl TE, Todo S, Fung J, Demetris AJ, Venkataramman R, Jain A (1989) FK 506 for liver, kidney, and pancreas transplantation. Lancet 2:1000-1004.

5. McCormack PL, Keating GM (2006) Tacrolimus: in heart transplant recipients. Drugs 66:2269-2279.

6. Banner NR (2006) Tacrolimus: In heart transplant recipients - A viewpoint by Nicholas R. Banner. Drugs $6 \overline{6}: 2280-2282$.

7. Higgins, J. P. and Green, S.Cochrane Handbook for Systematic Reviews of Interventions Version 5.0.2 [updated September 2009]. The Cochrane Collaboration, 2009. Available from www.cochrane-handbook.org.

Ref Type: Generic

8. Moher D, Liberati A, Tetzlaff J, Altman DG (2009) Preferred reporting items for systematic reviews and meta-analyses: the PRISMA statement. J.Clin.Epidemiol. 62:1006-1012.

9. Stewart S, Winters GL, Fishbein MC et al (2005) Revision of the 1990 working formulation for the standardization of nomenclature in the diagnosis of heart rejection. J.Heart Lung Transplant 24:1710-1720.

10. Royle P, Waugh N (2003) Literature searching for clinical and cost-effectiveness studies used in health technology assessment reports carried out for the National Institute for Clinical Excellence appraisal system. Health Technol.Assess. 7:iii, ix-51.

11. Schulz KF, Chalmers I, Hayes RJ, Altman DG (1995) Empirical evidence of bias. Dimensions of methodological quality associated with estimates of treatment effects in controlled trials. JAMA 273:408-412.

12. Higgins JP, Thompson SG (2002) Quantifying heterogeneity in a meta-analysis. Stat.Med. 21:1539-1558.

13. Altman DG, Bland JM (2003) Interaction revisited: the difference between two estimates. BMJ 326:219. 
14. Wetterslev J, Thorlund K, Brok J, Gluud C (2008) Trial sequential analysis may establish when firm evidence is reached in cumulative meta-analysis. J.Clin. Epidemiol. 61:64-75.

15. Grimm M, Rinaldi M, Yonan NA et al (2006) Superior prevention of acute rejection by tacrolimus vs. cyclosporine in heart transplant recipients - A large European trial. Ám J Transplant 6:1387-1397.

16. Kobashigawa J, Patel J, Furukawa $\mathrm{H}$ et al (2006) Five-year results of a randomized, singlecenter study of tacrolimus vs microemulsion cyclosporine in heart transplant patients. J.Heart Lung Transplant 25:434-439.

17. Kobashigawa JA, Miller LW, Russell SD (2004) A randomized, prospective, multicenter comparison of tacrolimus, mycopholate mofetil ( $\mathrm{mmf}$ ) and steroids vs cyclosporine microemulsion, $\mathrm{mmf}$ and steroids vs tacrolimus, sirolimus and steroids in de novo cardiac transplantation recipients - 6 month report. 3rd Int Congr Immunosuppr; 2004, San.Diego.

18. Kobashigawa JA, Patel JK, Furukawa H, Marquez A, Oeser BT, Laks H (2004) Five-year results of a randomized single center study of tacrolimus versus microemulsion cyclosporine in heart transplant patients. 3rd Int Congr Immunosuppr; 2004; San.Diego.

19. Kobashigawa JA, Miller LW, Russell SD et al (2006) Tacrolimus with mycophenolate mofetil (MMF) or sirolimus vs. Cyclosporine with MMF in cardiac transplant patients: 1year report. Am J Transplant 6:1377-1386.

20. Meiser BM, Groetzner J, Kaczmarek I et al (2004) Tacrolimus or cyclosporine: Which is the better partner for mycophenolate-mofetil in heart transplant recipients? Transplantation 78:591-598.

21. Meiser BM, Scheersoi T, Pfeiffer M et al (2000) Comparison of trough level adjusted MMF application in combination with either Cyclosporine or Tacrolimus in a randomized study after heart transplantation. Transplantation 69:695.

22. Meiser BM, Uberfuhr P, Fuchs A et al (1996) Comparison between Tacrolimus (FK506) and Cyclosporin A (CyA) after heart transplantation: A randomised, controlled clinical study. Zeitschr Kardiol 85 Suppl 2:133.

23. Meiser BM, Uberfuhr P, Fuchs A et al (1998) Single-center randomized trial comparing tacrolimus (FK506) and cyclosporine in the prevention of acute myocardial rejection. J Heart Lung Transplant 17:782-788.

24. Reichart B, Meiser B, Vigano M et al (1998) European multicenter tacrolimus (FK506) heart pilot study: One-year results-European tacrolimus multicenter heart study group. J Heart Lung Transplant 17:1998.

25. Pollock-BarZiv SMD, Dipchand AI, McCrindle BW, Nalli N, West LJ (2005) Randomized clinical trial of tacrolimus- vs cyclosporine-based immunosuppression in pediatric heart transplantation: Preliminary results at 15-month follow-up. J Heart Lung Transplant 24:Feb.
Formatted: Font: (Default) Arial, Complex Script Font: Arial

Formatted: Font: Italic

Formatted: Font: (Default) Arial, Complex Script Font: Arial

Formatted: Font: Italic Formatted: Font: (Default) Arial Complex Script Font: Arial

Formatted: Font: (Default) Arial, Complex Script Font: Arial

Formatted: Font: (Default) Arial Complex Script Font: Arial

Formatted: Font: Italic

Formatted: Font: (Default) Arial, Complex Script Font: Arial

Formatted: Font: Italic

Formatted: Font: (Default) Arial Complex Script Font: Arial

Formatted: Font: Italic Formatted: Font: (Default) Arial Complex Script Font: Arial

Formatted: Font: Italic Formatted: Font: (Default) Arial Complex Script Font: Arial

Formatted: Font: Italic

Formatted: Font: (Default) Arial, Complex Script Font: Arial

Formatted: Font: Italic

Formatted: Font: (Default) Arial, Complex Script Font: Arial

Formatted: Font: (Default) Arial Complex Script Font: Arial 
26. Rinaldi M, Pellegrini C, Martinelli L et al (1997) FK506 effectiveness in reducing acute rejection after heart transplantation: a prospective randomized study. J. Jeart Lung Transplant 16:1001-1010.

27. Taylor DO, Barr ML, Radovancevic B et al (1999) A randomized, multicenter comparison of tacrolimus and cyclosporine immunosuppressive regimens in cardiac transplantation: decreased hyperlipidemia and hypertension with tacrolimus. The Journal of heart and lung transplantation : the official.publication.of the International Society for.Heart Transplantation 18:336-345.

28. Wang CH, Ko WJ, Chou N, Wang SS (2004) Efficacy and safety of tacrolimus versus cyclosporine microemulsion in primary cardiac transplant recipients: 6-month results in Taiwan. Transplant Proc 36:2384-2385.

29. Wang $\mathrm{CH}, \mathrm{Ko}$ WJ, Chou N, Wang SS (2004) Therapeutic drug monitoring of tacrolimus in cardiac transplant recipients: A comparison with cyclosporine neoral. Transplant Proc 36:2386-2387.

30. Wang SS, Chou NK, Chi NH et al (2008) Heart transplantation under cyclosporine or tacrolimus combined with mycophenolate mofetil or everolimus. Transplant Proc 40:26072608.

31. Groetzner J, Meiser BM, Schirmer J et al (2001) Tacrolimus or cyclosporine for immunosuppression after cardiac transplantation: which treatment reveals more side effects during long-term follow-up? Transplant Proc 33:1461-1464.

32. Groetzner J, Meiser B, Schirmer J et al (2001) Tacrolimus/Mycophenolate mofetil vs Cyclosporine/Mycophenolate mofetil: Comparison of Mycophenolate mofetil acid trough levels and coronary vasomotor function. J Heart Lung Transplant 20:191.

33. Groetzner J, Meiser B, Schirmer J et al (2002) Tacrolimus/Mycophenolate Mofetil vs Cyclosporine/Mycophenolate Mofetil: Impact on infections following cardiac transplantation. J Heart Lung Transplant 21:120.

34. Schirmer J, Meiser B, Kadner A et al (2001) Tacrolimus versus cyclosporine after HTX: Comparison of long-term effects. J Heart Lung Transplant 20:191.

35. Grimm M, Rinaldi M, Yonan NA (2003) Efficacy and safety of Tacrolimus (TAC) vs. Cyclosporine microemulsion (CME) in de novo cardiac transplant recipients: 6-month results. J Heart Lung TransplantS92.

36. Taylor DO, Barr ML, Radovancevic B et al (1997) A comparison of tacrolimus- and cyclosporine-based immunosuppression in cardiac transplantation. J Heart Lung Transplant $\underline{16 .}$

37. Petrakopoulou P, Anthopoulou L, Muscholl M et al (2006) Coronary endothelial vasomotor function and vascular remodeling in heart transplant recipients randomized for tacrolimus or cyclosporine immunosuppression. JACC 47:1622-1629.

Formatted: Font: Italic Formatted: Font: (Default) Arial, Complex Script Font: Arial

Formatted: Font: (Default) Arial Complex Script Font: Arial

Formatted: Font: (Default) Arial Complex Script Font: Arial

Formatted: Font: Italic

Formatted: Font: (Default) Arial, Complex Script Font: Arial

Formatted: Font: Italic

Formatted: Font: (Default) Arial Complex Script Font: Arial

Formatted: Font: Italic

Formatted: Font: (Default) Arial, Complex Script Font: Arial

Formatted: Font: (Default) Arial, Complex Script Font: Arial

Formatted: Font: Italic

Formatted: Font: (Default) Arial, Complex Script Font: Arial

Formatted: Font: Italic

Formatted: Font: (Default) Arial, Complex Script Font: Arial 
38. Steinbüchel Nv, Limm H, Leopold C, Carr D (2000) Assessment of health-related qualityof-life in patients after heart transplantation under therapy with tacrolimus or cyclosporine. Transpl Int 13 Suppl 1:S609-S614.

39. Reichart B, Meiser B, Vigano M et al (2001) European multicenter tacrolimus heart pilot study: three year follow-up. J.Heart Lung Transplant. 20:249-250.

40. Gluud LL (2006) Bias in clinical intervention research. Am.J.Epidemiol. 163:493-501.

41. Eisen HJ, Hobbs RE, Davis SF et al (2001) Safety, tolerability, and efficacy of cyclosporine microemulsion in heart transplant recipients: a randomized, multicenter, double-blind comparison with the oil-based formulation of cyclosporine--results at 24 months after transplantation. Transplantation 71:70-78.

42. Podesser BK, Rinaldi M, Yona NA et al (2005) Comparison of low and high initial tacrolimus dosing in primary heart transplant recipients: A prospective European multicenter study. Transplantation 79:65-71.

43. Cantarovich M, Barkun J, Giannetti N, Cecere R, Besner JG, Tchervenkov J (2004) History of $\mathrm{C} 2$ monitoring in heart and liver transplant patients treated with cyclosporine microemulsion. Transplant Proc. 36:442S-447S.

44. Iversen M, Nilsson F, Sipponen J et al (2009) Cyclosporine C2 levels have impact on incidence of rejection in de novo lung but not heart transplant recipients: the NOCTURNE study. J.Heart Lung Transplant 28:919-926.

45. Fan Y, Xiao YB, Weng YG, Hetzer R (2009) Tacrolimus Versus Cyclosporine Microemulsion for Heart Transplant Recipients: A Meta-analysis. J Heart Lung Transplant 28:58-66.

46. Mehra MR, Uber PA, Park MH, Prasad AK, Scott RL (2001) A randomized comparison of an immunosuppressive strategy using tacrolimus and cyclosporine in black heart transplant recipients. Transplant Proc 33:1606-1607.

47. McAlister VC, Haddad E, Renouf E, Malthaner RA, Kjaer MS, Gluud LL (2006) Cyclosporin versus tacrolimus as primary immunosuppressant after liver transplantation: a meta-analysis. Am.J.Transplant 6:1578-1585.

48. Webster AC, Woodroffe RC, Taylor RS, Chapman JR, Craig JC (2005) Tacrolimus versus ciclosporin as primary immunosuppression for kidney transplant recipients: meta-analysis and meta-regression of randomised trial data. BMJ 331:810-821.

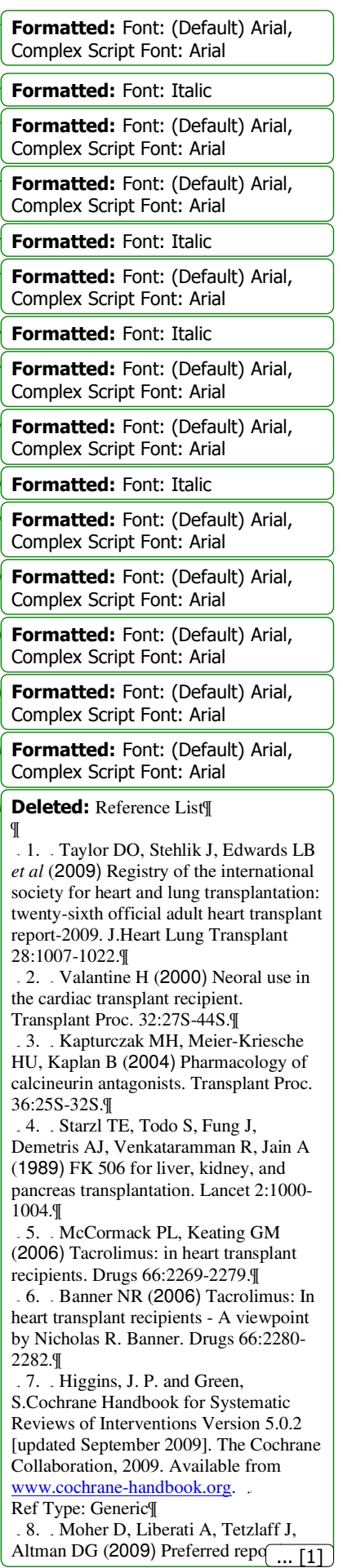




\section{Page 25 of 79}

3

\begin{tabular}{|l|l|l|l|l|l|}
\hline Trial & $\begin{array}{l}\text { Number } \\
\text { of patients }\end{array}$ & $\begin{array}{l}\text { Age }(\text { Y }) \\
\text { Tac/ Cyclo }\end{array}$ & $\begin{array}{l}\text { Follow- } \\
\text { up period } \\
\text { (mo })\end{array}$ & $\begin{array}{l}\text { Adult/ } \\
\text { Paediat } \\
\text { ric }\end{array}$ & $\begin{array}{l}\text { Oil-based /micro- } \\
\text { emulsion } \\
\text { Cyclosporine }\end{array}$ \\
\hline Rinaldi 1997 & 25 & $49 / 53$ & 12 & A & Oil-based \\
\hline Reichart 1998 & 82 & $50 / 52$ & 36 & A & Oil-based \\
\hline Taylor 1999 & 85 & $53 / 53$ & 12 & A & Oil-based \\
\hline Meiser 2004 & 60 & $55 / 55$ & 24 & A & Micro emulsion \\
\hline Wang 2004 & 21 & $49 / 44$ & 6 & A & Micro emulsion \\
\hline $\begin{array}{l}\text { Pollock- } \\
\text { BarZiv 2005 }\end{array}$ & 26 & $4 / 5$ & 26 & P & Micro emulsion \\
\hline Grimm 2006 & 314 & $51 / 51$ & 18 & A & Micro emulsion \\
\hline $\begin{array}{l}\text { Kobashigawa } \\
\text { 2006 A }\end{array}$ & 67 & $34 / 28$ & 60 & A/P & Micro emulsion \\
\hline $\begin{array}{l}\text { Kobashigawa } \\
\text { 2006 B }\end{array}$ & 223 & $54 / 51$ & 12 & A & Micro emulsion \\
\hline Wang 2008 & 49 & $\begin{array}{l}\text { Un } \\
\text { known }\end{array}$ & 36 & A & Micro emulsion \\
\hline
\end{tabular}

Table 1. Characteristics of included trials. 
Table 2 Assessment of methodology quality

\begin{tabular}{|l|l|l|l|l|l|}
\hline Trial & Allocation & Allocation & Blinding & Intention & Incomplete outcome \\
& sequence & concealment & & to treat & data addressed \\
\hline Rinaldi 1997 & Unclear & Unclear & No- only biopsies & Yes & Yes \\
\hline Reichart 1998 & Adequate & Adequate & No & Yes & Yes \\
\hline Taylor 1999 & Unclear & Adequate & No- only biopsies & Unclear & Unclear \\
\hline Meiser 2004 & Unclear & Unclear & No & Yes & Yes \\
\hline Wang 2004 & Unclear & Unclear & No & Yes & Unclear \\
\hline Pollock-BarZiv & Unclear & Unclear & No- only biopsies & Yes & Yes \\
\hline Grimm 2006 & Adequate & Adequate & No- only biopsies & Yes & Yes \\
\hline Kobashigawa & Unclear & Unclear & No-only biopsies and & Yes & Yes \\
\hline Ko06 A & & & coronary angiography & & Yes \\
\hline Kabashigawa & Unclear & Unclear & Unclear & Yes & Yes \\
\hline
\end{tabular}


Figure legends

Figure 1. Diagram of identification of randomized trials for inclusion

Figure 2. Intervention effect of tacrolimus vs. cyclosporine on mortality

Figure 3. Intervention effect of tacrolimus vs. cyclosporine on biopsy proven acute rejection $\geq 3 \mathrm{a}$

Figure 4. Intervention effect of tacrolimus vs. cyclosporine on hypertension

Figure 5. Intervention effect of tacrolimus vs. cyclosporine on hyperlipidaemia requiring treatment Figure 6. Intervention effect of tacrolimus vs. cyclosporine on post-transplant diabetes

Figure legends to supplementary electronic material

Figure 7. Intervention effect of tacrolimus vs. cyclosporine on rejection causing hemodynamic instability

Figure 8. Intervention effect of tacrolimus vs. cyclosporine on infection rate

Figure 9. Intervention effect of tacrolimus vs. cyclosporine on CMV-infection rate

Figure 10. Intervention effect of tacrolimus vs. cyclosporine on malignancy

Figure 11. Intervention effect of tacrolimus vs. cyclosporine on basocellular skin cancer

Figure 12. Intervention effect of tacrolimus vs. cyclosporine on renalfailure requiring haemodialysis

Figure 13. Intervention effect of tacrolimus vs. cyclosporine on serum creatinine $(\mu \mathrm{mol} / \mathrm{L})$

Figure 14. Intervention effect of tacrolimus vs. cyclosporine on chronic allograft vasculopathy

Figure 15. Intervention effect of tacrolimus vs. cyclosporine on hirsutism

Figure 16. Intervention effect of tacrolimus vs. cyclosporine on gingival hyperplasia

Figure 17. Intervention effect of tacrolimus vs. cyclosporine on neurotoxicity 
Figure 18. Intervention effect of tacrolimus vs. cyclosporine on total blood cholesterol (mmol/L)

\begin{tabular}{|c|c|c|c|c|c|}
\hline Trial & $\begin{array}{l}\text { Type of } \\
\text { cyclosporine }\end{array}$ & $\begin{array}{l}\text { Cyclosporine } \\
\text { trough } \\
\text { target/dose }\end{array}$ & $\begin{array}{l}\text { Tacrolimus dose } \\
(\mathrm{mg} / \mathrm{kg} / \mathrm{d}) / \\
\text { Target }(\mathrm{ng} / \mathrm{dl})\end{array}$ & $\begin{array}{l}\text { Azathioprine } \\
\text { /MMF dose }\end{array}$ & Inductiontherapy \\
\hline Rinaldi 1997 & Oil-based & $\begin{array}{l}\text { 0-1 mo: } 180-360 \\
>1 \mathrm{mo}: 80-180 \\
(2-6 \mathrm{mg} / \mathrm{kg} / \mathrm{d})\end{array}$ & $\begin{array}{l}0-12: 15-25(0.15 \\
\mathrm{mg} / \mathrm{kg} / \mathrm{d}) \\
\text { Reduced during study }\end{array}$ & $\begin{array}{l}\text { Azathioprine: } \\
\text { Pre-operat: } \\
4 \mathrm{mg} / \mathrm{kg} \\
\text { Maintenance: } 1-2 \\
\mathrm{mg} / \mathrm{kg}\end{array}$ & Yes, Rabbit ATG \\
\hline $\begin{array}{l}\text { Reichart } \\
1998\end{array}$ & Oil-based & $\begin{array}{l}\text { 0-6 mo: } 200-400 \\
>6 \text { mo: } 150-250\end{array}$ & $\begin{array}{l}0-28 \mathrm{~d}: 15-25(0.3 \\
\mathrm{mg} / \mathrm{kg} / \mathrm{d} ; \\
>28 \mathrm{~d}: 10-20 \\
\text { Later adjusted to } 0-12 \\
\mathrm{mo:}<15(<0.3 \\
\mathrm{mg} / \mathrm{kg} / \mathrm{d}\end{array}$ & $\begin{array}{l}\text { Azathioprine: } \\
210+/-147 \\
\text { Cum. Dosis } \\
\text { (Tacrolimus treatm } \\
\text { gr.) } \\
324+/-125 \\
\text { Cum. Dosis } \\
\text { (Ciclosporin treatm } \\
\text { gr.) }\end{array}$ & Partly, ATG \\
\hline Taylor 1999 & Oil-based & $\begin{array}{l}\text { 0-1 mo: } 250-600 \\
\text { 1-3 mo: } 200-400 \\
>3 \text { mo: } 150-250\end{array}$ & $\begin{array}{l}\text { 0-1 mo: } 10-20 \\
1-3 \mathrm{mo}: 10-15 \\
>3 \mathrm{mo}: 5-10\end{array}$ & $\begin{array}{l}\text { Azathioprine: } \\
\text { Pre-operat: } \\
4 \mathrm{mg} / \mathrm{kg} \\
\text { Maintenance: } 2 \mathrm{mg} / \mathrm{kg}\end{array}$ & $\begin{array}{l}\text { Partly, OKT3 in } \\
\text { high-risk patients }\end{array}$ \\
\hline Meiser 2004 & $\begin{array}{l}\text { Micro } \\
\text { emulsion }\end{array}$ & $\begin{array}{l}\text { 0-6 mo: } 200-300 \\
>6 \text { mo: } 100-200\end{array}$ & $\begin{array}{l}\text { 0-6 mo: } 13-15 \\
>6 \text { mo: } 10-12\end{array}$ & $\begin{array}{l}\text { MMF: } \\
0-6 \mathrm{mo}: 2.5-4 \mathrm{ug} / \mathrm{ml} \\
>3 \mathrm{mo}: 5-15\end{array}$ & No \\
\hline Wang 2004 & $\begin{array}{l}\text { Micro } \\
\text { emulsion }\end{array}$ & $\begin{array}{l}0-3 \mathrm{mo}: 300 \\
(6 \mathrm{mg} / \mathrm{kg} / \mathrm{d})\end{array}$ & $\begin{array}{l}0-3 \mathrm{mo}: 10-20(0.15 \\
\mathrm{mg} / \mathrm{kg} / \mathrm{d} ; \\
>3 \mathrm{mo}: 5-15\end{array}$ & Azathioprine & Yes, Rabbit ATG \\
\hline $\begin{array}{l}\text { Pollock- } \\
\text { BarZiv } 2005\end{array}$ & $\begin{array}{l}\text { Micro } \\
\text { emulsion }\end{array}$ & $\begin{array}{l}0-6 \mathrm{mo}: 250-325 \\
(6-10 \mathrm{mg} / \mathrm{kg} / \mathrm{d}) \\
>6 \mathrm{mo}: 200-250\end{array}$ & $\begin{array}{l}0-6 \mathrm{mo}: 10-12(0.1- \\
0.3 \mathrm{mg} / \mathrm{kg} / \mathrm{d} ; \\
>6 \mathrm{mo}: 8-10\end{array}$ & $\begin{array}{l}\text { Azathioprine } \\
2-3 \mathrm{mg} / \mathrm{kg} / \mathrm{d}\end{array}$ & $\begin{array}{l}\text { Yes, Polyclonal } \\
\text { Rabbit ATG }\end{array}$ \\
\hline Grimm 2006 & $\begin{array}{l}\text { Micro } \\
\text { emulsion }\end{array}$ & $\begin{array}{l}\text { 1-3 mo: } 200-350 \\
>3 \mathrm{mo}: 100-200\end{array}$ & $\begin{array}{l}\text { 1-3 mo: } 10-20 \\
>3 \mathrm{mo}: 5-15\end{array}$ & $\begin{array}{l}\text { Azathioprine } \\
2-4 \mathrm{mg} / \mathrm{kg} / \mathrm{d} ; \\
\text { WBC }>2000 \text { cells/ul }\end{array}$ & Yes, ATG or OKT3 \\
\hline $\begin{array}{l}\text { Kobashigawa } \\
2006 \text { A }\end{array}$ & $\begin{array}{l}\text { Micro } \\
\text { emulsion }\end{array}$ & $\begin{array}{l}\text { 0-1 mo: } 250-350 \\
\text { >1 mo: } 150-250\end{array}$ & $\begin{array}{l}\text { 0-1 mo: } 10-15 \\
>1 \text { mo: } 5-10\end{array}$ & $\begin{array}{l}\text { Azathioprine } 2 \\
\mathrm{mg} / \mathrm{kg} / \mathrm{d} ; \text { WBC }>3500 \\
\text { cells/ul }\end{array}$ & No \\
\hline $\begin{array}{l}\text { Kobashigawa } \\
2006 \text { B }\end{array}$ & $\begin{array}{l}\text { Micro } \\
\text { emulsion }\end{array}$ & $\begin{array}{l}\text { 0-3 mo: } 200-400 \\
>3 \mathrm{mo}: 100-300\end{array}$ & $\begin{array}{l}\text { 0-3 mo: } 10-20 \\
>3 \text { mo: } 5-15\end{array}$ & $\begin{array}{l}\text { MMF: } \\
\text { Start } 3 \mathrm{~g} / \mathrm{d} \\
\text { Target whole blood } \\
\text { trough conc } 3-5 \\
\mathrm{ng} / \mathrm{mL}\end{array}$ & $\begin{array}{l}\text { Partly, ATGAM, } \\
\text { OKT3 or RATG } \\
\text { allowed, and only } \\
\text { encouraged with } \\
\text { renal dysfunction }\end{array}$ \\
\hline Wang 2008 & $\begin{array}{l}\text { Micro } \\
\text { emulsion }\end{array}$ & Unknown & Unknown & MMF & Yes, type unknown \\
\hline
\end{tabular}

Supplementary material:

Table 3 Immunosuppressive treatment strategies of included trials 
Reference List

1. Taylor DO, Stehlik J, Edwards LB et al (2009) Registry of the international society for heart and lung transplantation: twenty-sixth official adult heart transplant report-2009. J.Heart Lung Transplant 28:1007-1022.

2. Valantine $H(2000)$ Neoral use in the cardiac transplant recipient. Transplant Proc. 32:27S-44S.

3. Kapturczak MH, Meier-Kriesche HU, Kaplan B (2004) Pharmacology of calcineurin antagonists. Transplant Proc. 36:25S-32S.

4. Starzl TE, Todo S, Fung J, Demetris AJ, Venkataramman R, Jain A (1989) FK 506 for liver, kidney, and pancreas transplantation. Lancet 2:1000-1004.

5. McCormack PL, Keating GM (2006) Tacrolimus: in heart transplant recipients. Drugs 66:2269-2279.

6. Banner NR (2006) Tacrolimus: In heart transplant recipients - A viewpoint by Nicholas R. Banner. Drugs 66:2280-2282.

7. Higgins, J. P. and Green, S.Cochrane Handbook for Systematic Reviews of Interventions Version 5.0.2 [updated September 2009]. The Cochrane Collaboration, 2009. Available from www.cochrane-handbook.org. Ref Type: Generic

8. Moher D, Liberati A, Tetzlaff J, Altman DG (2009) Preferred reporting items for systematic reviews and meta-analyses: the PRISMA statement. J.Clin.Epidemiol. 62:1006-1012.

9. Stewart S, Winters GL, Fishbein MC et al (2005) Revision of the 1990 working formulation for the standardization of nomenclature in the diagnosis of heart rejection. J.Heart Lung Transplant 24:1710-1720.

10. Royle P, Waugh N (2003) Literature searching for clinical and cost-effectiveness studies used in health technology assessment reports carried out for the National Institute for Clinical Excellence appraisal system. Health Technol.Assess. 7:iii, ix-51.

11. Schulz KF, Chalmers I, Hayes RJ, Altman DG (1995) Empirical evidence of bias. Dimensions of methodological quality associated with estimates of treatment effects in controlled trials. JAMA 273:408-412. 
12. Higgins JP, Thompson SG (2002) Quantifying heterogeneity in a meta-analysis. Stat.Med. 21:1539-1558.

13. Altman DG, Bland JM (2003) Interaction revisited: the difference between two estimates. BMJ 326:219.

14. Wetterslev J, Thorlund K, Brok J, Gluud C (2008) Trial sequential analysis may establish when firm evidence is reached in cumulative meta-analysis. J.Clin.Epidemiol. 61:64-75.

15. Grimm M, Rinaldi M, Yonan NA et al (2006) Superior prevention of acute rejection by tacrolimus vs. cyclosporine in heart transplant recipients - A large European trial. Am J Transplant 6:1387-1397.

16. Kobashigawa J, Patel J, Furukawa H et al (2006) Five-year results of a randomized, single-center study of tacrolimus vs microemulsion cyclosporine in heart transplant patients. J.Heart Lung Transplant 25:434-439.

17. Kobashigawa JA, Miller LW, Russell SD (2004) A randomized, prospective, multicenter comparison of tacrolimus, mycopholate mofetil (mmf) and steroids vs cyclosporine microemulsion, mmf and steroids vs tacrolimus, sirolimus and steroids in de novo cardiac transplantation recipients - 6 month report. 3rd Int Congr Immunosuppr; 2004, San.Diego.

18. Kobashigawa JA, Patel JK, Furukawa H, Marquez A, Oeser BT, Laks H (2004) Five-year results of a randomized single center study of tacrolimus versus microemulsion cyclosporine in heart transplant patients. 3rd Int Congr Immunosuppr; 2004; San.Diego.

19. Kobashigawa JA, Miller LW, Russell SD et al (2006) Tacrolimus with mycophenolate mofetil (MMF) or sirolimus vs. Cyclosporine with MMF in cardiac transplant patients: 1-year report. Am J Transplant 6:1377-1386.

20. Meiser BM, Groetzner J, Kaczmarek I et al (2004) Tacrolimus or cyclosporine: Which is the better partner for mycophenolate-mofetil in heart transplant recipients? Transplantation 78:591-598.

21. Meiser BM, Scheersoi T, Pfeiffer M et al (2000) Comparison of trough level adjusted MMF application in combination with either Cyclosporine or Tacrolimus in a randomized study after heart transplantation. Transplantation 69:695.

22. Meiser BM, Uberfuhr P, Fuchs A et al (1996) Comparison between Tacrolimus (FK506) and Cyclosporin A (CyA) after heart transplantation: A randomised, controlled clinical study. Zeitschr Kardiol 85 Suppl 2:133. 
23. Meiser BM, Uberfuhr P, Fuchs A et al (1998) Single-center randomized trial comparing tacrolimus (FK506) and cyclosporine in the prevention of acute myocardial rejection. J Heart Lung Transplant 17:782-788.

24. Reichart B, Meiser B, Vigano M et al (1998) European multicenter tacrolimus (FK506) heart pilot study: One-year results-European tacrolimus multicenter heart study group. J Heart Lung Transplant 17:1998.

25. Pollock-BarZiv SMD, Dipchand AI, McCrindle BW, Nalli N, West LJ (2005) Randomized clinical trial of tacrolimus- vs cyclosporine-based immunosuppression in pediatric heart transplantation: Preliminary results at 15month follow-up. J Heart Lung Transplant 24:Feb.

26. Rinaldi M, Pellegrini C, Martinelli L et al (1997) FK506 effectiveness in reducing acute rejection after heart transplantation: a prospective randomized study. J.Heart Lung Transplant 16:1001-1010.

27. Taylor DO, Barr ML, Radovancevic B et al (1999) A randomized, multicenter comparison of tacrolimus and cyclosporine immunosuppressive regimens in cardiac transplantation: decreased hyperlipidemia and hypertension with tacrolimus. The Journal of heart and lung transplantation : the official.publication. of the International Society for.Heart Transplantation 18:336345.

28. Wang CH, Ko WJ, Chou N, Wang SS (2004) Efficacy and safety of tacrolimus versus cyclosporine microemulsion in primary cardiac transplant recipients: 6month results in Taiwan. Transplant Proc 36:2384-2385.

29. Wang CH, Ko WJ, Chou N, Wang SS (2004) Therapeutic drug monitoring of tacrolimus in cardiac transplant recipients: A comparison with cyclosporine neoral. Transplant Proc 36:2386-2387.

30. Wang SS, Chou NK, Chi NH et al (2008) Heart transplantation under cyclosporine or tacrolimus combined with mycophenolate mofetil or everolimus. Transplant Proc 40:2607-2608.

31. Groetzner J, Meiser BM, Schirmer J et al (2001) Tacrolimus or cyclosporine for immunosuppression after cardiac transplantation: which treatment reveals more side effects during long-term follow-up? Transplant Proc 33:1461-1464.

32. Groetzner J, Meiser B, Schirmer J et al (2001) Tacrolimus/Mycophenolate mofetil vs Cyclosporine/Mycophenolate mofetil: Comparison of Mycophenolate mofetil acid trough levels and coronary vasomotor function. J Heart Lung Transplant 20:191. 
33. Groetzner J, Meiser B, Schirmer J et al (2002) Tacrolimus/Mycophenolate Mofetil vs Cyclosporine/Mycophenolate Mofetil: Impact on infections following cardiac transplantation. J Heart Lung Transplant 21:120.

34. Schirmer J, Meiser B, Kadner A et al (2001) Tacrolimus versus cyclosporine after HTX: Comparison of long-term effects. J Heart Lung Transplant 20:191.

35. Grimm M, Rinaldi M, Yonan NA (2003) Efficacy and safety of Tacrolimus (TAC) vs. Cyclosporine microemulsion (CME) in de novo cardiac transplant recipients: 6-month results. J Heart Lung TransplantS92.

36. Taylor DO, Barr ML, Radovancevic B et al (1997) A comparison of tacrolimusand cyclosporine-based immunosuppression in cardiac transplantation. J Heart Lung Transplant 16.

37. Petrakopoulou P, Anthopoulou L, Muscholl M et al (2006) Coronary endothelial vasomotor function and vascular remodeling in heart transplant recipients randomized for tacrolimus or cyclosporine immunosuppression. JACC 47:16221629.

38. Steinbüchel Nv, Limm H, Leopold C, Carr D (2000) Assessment of healthrelated quality-of-life in patients after heart transplantation under therapy with tacrolimus or cyclosporine. Transpl Int 13 Suppl 1:S609-S614.

39. Reichart B, Meiser B, Vigano M et al (2001) European multicenter tacrolimus heart pilot study: three year follow-up. J.Heart Lung Transplant. 20:249-250.

40. Gluud LL (2006) Bias in clinical intervention research. Am.J.Epidemiol. 163:493-501.

41. Eisen HJ, Hobbs RE, Davis SF et al (2001) Safety, tolerability, and efficacy of cyclosporine microemulsion in heart transplant recipients: a randomized, multicenter, double-blind comparison with the oil-based formulation of cyclosporine--results at 24 months after transplantation. Transplantation 71:70-78.

42. Podesser BK, Rinaldi M, Yona NA et al (2005) Comparison of low and high initial tacrolimus dosing in primary heart transplant recipients: A prospective European multicenter study. Transplantation 79:65-71.

43. Fan Y, Xiao YB, Weng YG, Hetzer R (2009) Tacrolimus Versus Cyclosporine Microemulsion for Heart Transplant Recipients: A Meta-analysis. J Heart Lung Transplant 28:58-66.

44. Mehra MR, Uber PA, Park MH, Prasad AK, Scott RL (2001) A randomized comparison of an immunosuppressive strategy using tacrolimus and cyclosporine in black heart transplant recipients. Transplant Proc 33:1606-1607. 
45. McAlister VC, Haddad E, Renouf E, Malthaner RA, Kjaer MS, Gluud LL (2006) Cyclosporin versus tacrolimus as primary immunosuppressant after liver transplantation: a meta-analysis. Am.J.Transplant 6:1578-1585.

46. Webster AC, Woodroffe RC, Taylor RS, Chapman JR, Craig JC (2005) Tacrolimus versus ciclosporin as primary immunosuppression for kidney transplant recipients: meta-analysis and meta-regression of randomised trial data. BMJ 331:810-821. 


\section{Tacrolimus versus cyclosporine as primary immunosuppression after heart transplantation:}

Systematic review with meta-analyses and trial sequential analyses of randomized trials

Luit Penninga $^{1,2}$, Christian H Møller ${ }^{1,3}$, Finn Gustafsson ${ }^{4}$, Daniel A Steinbrüchel ${ }^{3}$, Christian Gluud $^{1}$

${ }^{1}$ Copenhagen Trial Unit, Centre for Clinical Intervention Research, Cochrane Hepato-biliary

Group, Department 3344, Rigshospitalet, Copenhagen University Hospital, Copenhagen, Denmark

${ }^{2}$ Department of Surgery and Transplantation C2122, Rigshospitalet, Copenhagen University

Hospital, Copenhagen, Denmark

${ }^{3}$ Department of Cardiothoracic Surgery RT 2152, Rigshospitalet, Copenhagen University Hospital, Dept RT-2152, Copenhagen, Denmark

${ }^{4}$ Department of Cardiology, B2142, Rigshospitalet, Copenhagen University Hospital, Copenhagen, Denmark

Corresponding Author: Luit Penninga, MD

E-mail: $\underline{\text { LP@ @ctu.rh.dk }}$

Tel +45 3545 7113/ +4535457154

Fax +45 35457101 
Keywords Heart transplantation $\cdot$ Cyclosporine $\cdot$ Tacrolimus $\cdot$ Calcineurin inhibitors $\cdot$ Meta-analysis 


\section{Introduction}

The therapeutic success of heart transplantation has been largely attributable to the development of effective and balanced immunosuppressive treatment regimens [1,2]. Especially the calcineurin inhibitors were essential in reducing acute rejection and improving early survival [2]. Two calcineurin inhibitors, cyclosporine and tacrolimus, are currently used as primary immunosuppression in heart transplant recipients [1,2].

Cyclosporine was discovered in 1971, and in 1983 the drug was approved for prevention or treatment of transplant rejection [3]. To overcome the intra-individual and inter-individual differences in absorption and biovailability of the original oil-based formulation of cyclosporine (Sandimmune $\left.{ }^{\circledR}\right)$, a micro-emulsion formula of cyclosporine (Neoral®) was introduced in the 1990s [3].

Tacrolimus (Prograf®) was discovered in the early 1980s and from 1989 used for the prevention of liver transplant rejection [3,4]. Since then, its use expanded rapidly into transplantation of other organs [3]. Both cyclosporine and tacrolimus inhibit the action of the phosphatase calcineurin. Calcineurin regulates the transport of NFAT (nuclear factor of activated T-cells, which is a transcription factor regulating lymphokine gene transcription. Cyclosporine and tacrolimus exert their cellular effects on the action of calcineurin through different cytoplasmatic receptors, as cyclosporine binds to cyclophilins and tacrolimus binds to FK-binding proteins [5]. Differences in adverse effects, safety and tolerability between cyclosporine and tacrolimus have been observed, but the toxicodynamic molecular mechanism of both drugs are still largely unknown and the involvement of calcineurin inhibition in calcineurin inhibitir toxicity is unclear [6]. 
To date several randomized trials have compared tacrolimus vs. cyclosporine, but results have been inconsistent and optimal immunosuppressive maintenance therapy continues to be debated [5,6]. We conducted this systematic review to compare benefits and harms of tacrolimus vs. cyclosporine in heart transplant recipients.

\section{Methods \\ Trial selection and characteristics}

Our review followed the Cochrane Collaboration [7] and PRISMA guidelines [8]. A protocol was developed (www.ctu.dk/protocols) and we included all randomized trials comparing tacrolimus versus cyclosporine after first-time isolated heart-transplantation. We required that all included patients received the same additional immunosuppressive therapy within each trial. Our preselected outcome measures were mortality, acute severe rejection defined as cardiac biopsies of grade $3 \mathrm{~A}$ or higher according to the classification of the ISHLT (equivalent to grade H2R in the recently revised classification) [9]; acute rejection causing haemodynamic instability; Cytomegalovirus (CMV) infection; basocellular skin cancer; all malignancies excluding basocellular skin cancer; arterial hypertension; diabetes mellitus; hyperlipidaemia; total serum cholesterol; renal failure requiring haemodialysis; serum creatinine levels; neurotoxicity; hirsutism; and gingival hyperplasia. Our preselected subgroup analyses included 1) low-risk bias compared to high-risk bias trials 2) microemulsion cyclosporine compared to oil-based cyclosporine formulation 3) total population (adult and paediatric studies) compared to adult studies only (www.ctu.dk/protocols).

\section{Search strategy}

We searched The Cochrane Central Register of Controlled Clinical Trials (CENTRAL), MEDLINE, EMBASE, and the Science Citation Index Expanded (to April 2010) [10]. Search terms 
were (c*closporin* or CyA or Neoral* or Sandimmun*) combined with (tacrolimus or FK506 or FK 506 or Prograf) and 'heart transplantation' [MESH term] and (random* or blind* or placebo* or meta-analysis).

We scanned bibliographies of relevant articles for additional trials. We had no restrictions to blinding, language, or publication status.

\section{Data extraction and quality assessment}

Three authors independently assessed trial eligibility (LP, CHM and FG). We assessed the impact of bias risk by evaluating the trials with respect to generation of the allocation sequence, allocation concealment, blinding, and reporting of incomplete outcome data [11]. Generation of the allocation sequence was considered adequate when generated by a computer, random-number table, shuffling of cards, or something similar. Allocation concealment was considered adequate when allocation of patients involved a central independent unit, such as an on-site locked computer, sealed envelopes or something similar. Blinding was adequate if the trial was described as double-blind and the method of blinding involved identical active drugs. Post-randomization exclusion of patients was registered. When possible we converted per-protocol to intention-to-treat-analysis. Bias risk was assessed without blinding by 3 authors [11].

\section{Quantitative data synthesis}

We used Cochrane Collaboration Software (RevMan 5.0.22). Data were analysed with both fixedeffect and random-effects models. In case of discrepancy regarding significance between the two models both results were reported. Otherwise, only results from the random-effects model were reported. Data were presented as relative risk (RR) with values less than 1.0 favouring tacrolimus, 
and with $95 \%$ confidence intervals (CI). Heterogeneity was assessed with $\mathrm{I}^{2}$, which describes the percentage of the variability in effect estimates that is due to heterogeneity rather than sampling error (chance). $\mathrm{I}^{2}$ lies between $0 \%$ (no heterogeneity) and 100\% (maximal heterogeneity) [12]. Test of interaction was performed to evaluate the difference between the 2 estimates [13].

\section{Trial sequential analysis}

Trial sequential analysis was applied as cumulative meta-analyses are at risk of producing random errors because of sparse data or repetitive testing on accumulating data [14]. To minimize random errors we calculated the required information size (i.e., the number of participants needed in a metaanalysis to detect or reject a certain intervention effect) [14]. Information size calculation also accounted for the diversity present in the meta-analysis. In our meta-analysis, information size was based on the assumption of a plausible RR reduction of $20 \%$ [14]. The underlying assumption of trial sequential analysis is that significance testing may be performed each time a new trial is added to the meta-analysis. We added the trials according to the year of publication. On the basis of the required information size and risk for type I and type II errors trial sequential monitoring boundaries were constructed [14]. These boundaries will determine the statistical inference one may draw regarding the cumulative meta-analysis that has not reached the required information size. If a trial sequential monitoring boundary is crossed before the required information size is reached in a cumulative meta-analysis, firm evidence may have been established and further trials are superfluous. On the other hand, if the boundaries are not surpassed, it is most probably necessary to continue doing trials in order to detect or reject a certain intervention effect. We used as defaults a type I error of $5 \%$, type II error of $20 \%$, and adjusted the information size for diversity unless otherwise stated [14]. 


\section{Results}

Figure 1 depicts the results of the search strategy. Database searches identified 450 references. Exclusion of duplicates and irrelevant references left 11 randomized trials published in 25 publications [15-39]. One trial could not be included in the meta-analysis as none of the outcome measures were addressed [29]. We confirmed with the authors that all patients only participated once in the trials $[28,30]$

The meta-analyses involved 10 trials with a total of 952 patients (table 1): 486 patients were randomized to tacrolimus and 466 patients to cyclosporine $[15,16,19,20,24-28,30])$. Three trials with 192 patients compared tacrolimus with the old formula oil-based cyclosporine [24,26,27] and seven trials with 760 patients compared tacrolimus with the new formula microemulsion cyclosporine $[15,16,19,20,25,28,30]$.

In 8 trials the population consisted of adult patients [15,19,20,24,26-28,30], while in 1 trial the population consisted of a combination of adult and paediatric patients [16], and in 1 trial only paediatric patients were included [25].

Concomitant immunosuppressive treatment was the same within all trials except for one where the patients were randomized to 3 groups: one receiving cyclosporine and mycophenolate mofetil, one receiving tacrolimus and mycophenolate mofetil, and one receiving tacrolimus and sirolimus [19]. We therefore excluded the latter group of our analyses. Immunosuppressive treatment varied within trials. All patients were treated with steroids. As antiproliferative agent azathioprine ( 7 trials [15,16,24-28]) or mycophenolate mofetil (3 trials $[19,20,30])$ was used. Induction therapy was used for all patients in 4 trials [15,25,26,28], for some of the patients in 3 trials [19,24,27], and for none 
in 3 trials $[16,20,30]$. In case induction therapy was used, either anti-thymocyte globulin (ATG) or muromonab-CD3 (OKT3®) was administered [15,25,26,28]. Patients were followed from 6 months to 5 years.

Trial methodology was inadequately reported in the majority of trials (table 2). All trials were considered trials with high risk of bias.

\section{Mortality}

Ten trials reported on mortality, and overall no significant difference in mortality was found between tacrolimus and cyclosporine (relative risk (RR) 0.78; $95 \%$ CI 0.54-1.13, p = 0.19). Tacrolimus was significantly superior to microemulsion cyclosporine (RR 0.64; 95\% CI 0.42-0.96, $\mathrm{p}=0.03$ ). No significant difference in mortality between tacrolimus and oil-based cyclosporine was found (RR 1.79; 95\% CI 0.77-4.15, p=0.17). Test of interaction showed significant difference in intervention effect on mortality between the oil-based and microemulsion cyclosporine formulas $(\mathrm{p}=0.04)$.

The significant difference in mortality between tacrolimus and microemulsion cyclosporine, however, disappeared when the studies including paediatric patients were excluded (RR 0.66; 95\% CI $0.40-1.09, \mathrm{p}=0.10)$. Test of interaction showed no significant differences in mortality between the paediatric and adult cyclosporine subgroups $(\mathrm{p}=0.89)$, This suggests that the lack of significance caused by withdrawing paediatric studies was solely caused by reducing the number of patients in the groups.

Acute rejection 


\section{Infections}

Infections were analysed as number of patients who experienced at least one episode of infection. No significant difference in proportion of patients with infection was found between tacrolimus and cyclosporine (RR 1.01; 95\% CI 0.84-1.21, $\mathrm{p}=0.91)$. Neither was any significant difference found when subgroup analysis for the microemulsion and oil-based cyclosporine was applied. In addition 2 trials compared number of patients with CMV infection for tacrolimus versus microemulsion cyclosporine, and no significant difference was found (RR 1.03; 95\% CI 0.75-1.42, p=0.85).

\section{Malignancies}

According to our protocol we analysed malignancies as basocellular skin cancer and all other cancers excluding basocellular skin cancer. Three trials found no significant difference between tacrolimus versus microemulsion cyclosporine on basocellular skin cancer (RR 1.20; 95\% CI 0.294.93, $\mathrm{p}=0.80$ ). Four trials reported on other cancers and found no significant difference between tacrolimus and cyclosporine (RR 0.57 ; 95\% CI 0.20-1.63, p=0.85). Nor did we find any significant difference when subgroup analysis for the microemulsion and oil-based cyclosporine was applied. 


\section{Hypertension}

Eight trials found significantly less hypertension in patients treated with tacrolimus compared with cyclosporine (RR 0.80; 95\% CI 0.69-0.93, p=0.003). In addition subgroup analysis showed that hypertension was less common for tacrolimus compared with oil-based cyclosporine (RR 0.66; 95\% CI 0.54-0.80, $\mathrm{p}<0.0001)$. An insignificant trend was seen towards less hypertension for tacrolimus compared with microemulsion cyclosporine (RR 0.88; 95\% CI 0.77-1.01, $\mathrm{p}=0.07$ ). The difference was significant when a fixed-effect model was applied (RR 0.86; 95\% CI 0.78-0.95, p=0.003).

\section{Hyperlipidaemia}

Four trials reported on the number of patients treated pharmacologically for hyperlipidaemia and 5 trials reported on total serum cholesterol. Significantly less patients treated with tacrolimus received treatment for hyperlipidaemia compared with cyclosporine (RR 0.57; 95\% CI 0.44-0.74, p<0.0001). This was both seen for patients treated with oil-based cyclosporine (RR 0.57; 95\% CI 0.38-0.87, $\mathrm{p}=0.009)$ and microemulsion cyclosporine (RR 0.57 95\% CI 0.41-0.79, p=0.0009). In addition, we found that tacrolimus significantly lowers total cholesterol compared with cyclosporine (mean difference $0.4 \mathrm{mmol} / \mathrm{L} ; 95 \% \mathrm{CI}-0.66$ to $-0.22 \mathrm{mmol} / \mathrm{L}, \mathrm{p}<0.0001$ ). This was both seen for the oil-based $(\mathrm{p}=0.005)$ as for the microemulsion $(\mathrm{p}=0.002)$ subgroups, and the effect was seen even though in some of the trials more patients in the cyclosporine group were on cholesterol lowering therapy.

\section{Diabetes}

Eight trials reported on diabetes. An insignificant trend towards more diabetes was seen in tacrolimus compared with cyclosporine (RR 1.35; 95\% CI 0.93-1.94, $\mathrm{p}=0.11$ ). No significant difference was seen for subgroup analyses on oil-based cyclosporine (RR 1.07, 95\% CI 0.40-2.90, 


\section{Renal function}

No significant difference between tacrolimus and cyclosporine was seen concerning renal failure requiring haemodialysis ( $\mathrm{RR} 1.45 ; 95 \%$ CI $0.50-4.26, \mathrm{p}=0.49$ ). In addition no significant difference was seen for subgroup analyses on oil-based cyclosporine and microemulsion cyclosporine. Serum creatinine at end of the trials $(n=6)$ was $8 \mu \mathrm{mol} / \mathrm{L}$ lower in patients treated with tacrolimus compared with cyclosporine, however, this difference was not significant (95\% CI -18.3 to -1.7 $\mu \mathrm{mol} / \mathrm{L}, \mathrm{p}=0.11$ ). Nor was any significant difference seen in serum creatinine for subgroup analyses on oil-based cyclosporine and microemulsion cyclosporine.

\section{Chronic allograft vasculopathy}

Five trials reported on chronic allograft vasculopathy, and no significant difference was found for tacrolimus compared with cyclosporine (RR 1.22; 95\% CI 0.72-2.05, $\mathrm{p}=0.46$ ). Nor was any difference found for subgroup analysis on oil-based cyclosporine and microemulsion cyclosporine.

\section{Hirsutism and gingival hyperplasia}

Hirsutism was reported in 2 trials and was significantly less frequent seen in patients treated with tacrolimus than microemulsion cyclosporine (RR 0.17; 95\% CI 0.04-0.62, $\mathrm{p}=0.008$ ). Gingival hyperplasia was reported in three trials and was significantly less frequent seen in patients treated with tacrolimus than with microemulsion cyclosporine (RR 0.07; 95\% CI 0.01-0.37, $\mathrm{p}=0.002$ ). 


\begin{abstract}
Neurotoxicity
Neurotoxicity was reported in 5 trials and was analysed as number of patients who experienced at least one neurotoxic reaction or stroke. No significant difference was observed (RR 1.31 ; 95\% CI 0.58-3.00, $\mathrm{p}=0.50$ ). Nor was any significant difference detected when subgroup analysis for the microemulsion and oil-based cyclosporine was applied.
\end{abstract}

Adult patients

We performed subgroup analysis for only adult patients by excluding the 2 trials including only or partly paediatric patients $[16,25]$. We did not find any differences for any of the outcome measures except for the difference in mortality, which was described above.

\title{
Trial sequential analysis
}

Trial sequential analysis was performed for the statistical significant differences in mortality seen for both the tacrolimus vs. oil-based cyclosporine group as well for the tacrolimus versus microemulsion cyclosporine group. In none of the analyses was the required information size obtained and none of the trials sequential monitoring boundaries were broken by the cumulative Zcurve.

\section{Discussion}

\section{Principal findings}

Our systematic review has generated a number of important findings. Tacrolimus seems to be significantly superior to both types of cyclosporine as regards hypertension, hyperlipidaemia, 


\section{Strengths}

Our systematic review of randomized trials offers a number of advantages. We conducted our review according to a protocol following the recommendations of the Cochrane Collaboration [7] and published our protocol before the conduct of the review (www.ctu.dk/protocols). We systematically searched a number of databases and reference lists for randomized trials, which should have reduced selection bias to a minimum [40]. We selected trials and extracted data in triplicate. We conducted sensitivity analyses using different models. We considered risk of systematic errors ('bias'), risks of random errors ('play of chance'), as well as risk of design errors (e.g., type of cyclosporine) [40]. We reported our findings in accordance with PRISMA [8].

\section{Limitations}

This systematic review also encompasses some limitations. The quality and quantity of available evidence limit our findings and interpretations. All trials had high risk of bias [40]. Moreover, only few patients with relatively few outcomes were included in the trials. Hence, risks of random errors are potential explanations of our findings as suggested by our trial sequential analyses on mortality. In addition, patients included in randomized trials may not be representative of the general patient population. For instance most trials included in the current review did not include patients who were bridged to transplantation with a left ventricular device. The proportion of patients bridged to transplantation with an assist device has been increasing in the general heart transplantation population and consisted of $19 \%$ in a recent analysis [1]. Moreover, in recent years heart transplant recipients have become older during the technical evolution, with currently $25 \%$ of all heart 
transplants performed in people over 60 years of age [1]. These factors could potentially influence the external validity of the included trials.

\section{Perspective}

In our meta-analysis tacrolimus was found superior to the new microemulsion cyclosporine concerning mortality in terms of risk of dying, but no significant difference between tacrolimus and the old formula oil-based cyclosporine was observed. The question arises how this difference can be explained, as microemulsion cyclosporine was introduced to overcome the differences in absorption and oral bioavailability of the original oil-based formulation of cyclosporine [2]. Microemulsion cyclosporine results in higher maximum cyclosporine concentrations than oil-based cyclosporine even when cyclosporine trough $(\mathrm{C} 0)$ levels are similar, which might influence tolerability and toxicity. A randomized multicenter trial comparing both cyclosporine formulas found more consistent bioavailability of the microemulsion formula resulting in less severe acute rejection in patients treated with the new formula, however, no significant difference in mortality was found at 24 months follow-up in 380 patients [41].

Concerning the difference in mortality observed for the two different cyclosporine formulas in our meta-analysis, it should be noted that clinical experience with tacrolimus was more limited in the trials comparing this drug with oil-based cyclosporine compared to the trials comparing tacrolimus with microemulsion cyclosporine, and tacrolimus blood target levels were higher in the trials with oil-based cyclosporine compared to the trials with microemulsion cyclosporine [15-21,21-28,30]. However, a randomized trial comparing low and high tacrolimus doses in heart transplant recipients did not find any significant difference in mortality, but a more favourable safety profile for the patients treated with a low tacrolimus dose [42]. 
Traditionally cyclosporine dosing has been based on trough cyclosporine level (C0) monitoring [43]. Cyclosporine level at 2 hours post-dose (C2) has though been found to be the best single timepoint point predictor of 0 to 4 -hour abbreviated area under the absorption curve $\left(\mathrm{AUC}_{0-4}\right)$ in heart, lung, kidney and liver transplant recipients $[43,44]$. Clinical benefits have been shown for other solid organ recipients when C2 monitoring was applied compared to C0 [44]. For heart transplant recipients the picture is more unclear as one large trial did not find a correlation between $\mathrm{C} 2$ levels and the incidence of rejection [44]. It appears though, that in general a lower C2 level may be sufficient to prevent rejection, and with lower levels different adverse effects might be expected $[43,44]$. None of the trials in this meta-analysis applied C2 levels for therapeutic drug monitoring of cyclosporine, and we were therefore not able to analyze $\mathrm{C} 0$ compared to $\mathrm{C} 2$ monitoring in our trial.

The statistical significant difference in mortality between tacrolimus and microemulsion cyclosporine disappeared when two trials including paediatric patients were excluded. However results for the different trials were consistent and none of the trials found tacrolimus to be inferior to cyclosporine. No significant difference between adult and paediatric patients was found when test of interaction was performed. This suggests that the lack of significance caused by withdrawing paediatric studies was caused by reducing the number of patients in the groups.

Our meta-analysis found tacrolimus to be associated with less severe acute biopsy proven rejection compared with microemulsion cyclosporine. This is in line with observational data from The ISHLT showing that $19 \%$ of patients who at transplant discharge were receiving tacrolimus and mycophenolate mofetil suffered a treated rejection as compared to $27 \%$ of patients receiving cyclosporine and mycophenolate mofetil $(\mathrm{p}<0.0001)[1]$. 
Another meta-analysis regarding tacrolimus versus microemulsion cyclosporine has been published, and results are slightly different from our systematic review [45]. This might be explained by the following: we found additional randomized trials comparing tacrolimus with microemulsion cyclosporine [30], we excluded studies which were not properly randomized [46], and we excluded study groups where there were differences in concomitant immunosuppressive medication between the tacrolimus and cyclosporine treatment groups [19]. Furthermore, we included trials comparing tacrolimus with oil-based cyclosporine [24,26,27].

Traditionally, immunosuppressive treatment for heart transplantation has gained much experience from knowledge regarding other types of organ transplantation. A meta-analysis comparing tacrolimus versus cyclosporine in 3813 liver transplant recipients found tacrolimus to be superior to cyclosporine in improving patient and graft survival and preventing acute rejection after liver transplantation, however, tacrolimus was significantly more diabetogenic than cyclosporine [47]. A meta-analysis comparing tacrolimus versus cyclosporine in 4102 kidney transplant recipients found tacrolimus to be superior to cyclosporine in improving graft survival and preventing acute rejection after kidney transplantation, however, tacrolimus was found to increase post-transplant diabetes, neurological, and gastrointestinal adverse effects [48]. The reduction in acute rejection and mortality seen in kidney and liver transplant recipients treated with tacrolimus was only seen in our subgroup of heart transplant recipients where tacrolimus was compared to microemulsion cyclosporine. In contrast to kidney and liver transplant recipients we did not find a significant difference on diabetes in heart transplant recipients, however, an insignificant trend towards more diabetes in the tacrolimus group was seen.

\section{Conclusion}


Recognizing the limitations of the study due to the size and nature of the included trials, our systematic review shows that tacrolimus seems superior to cyclosporine in heart transplant recipients regarding hypertension, hyperlipidaemia, hirsutism and gingival hyperplasia. In addition, tacrolimus seems to be superior to microemulsion cyclosporine regarding mortality and acute severe biopsy-proven rejection. Given the result of our analysis it appears that an appropriately sized, randomized trial of tacrolimus versus microemulsion cyclosporine using contemporary target levels and adjunctive immunosuppression in cardiac transplantation is warranted to determine if the results of the present meta-analysis can be confirmed.

\section{Acknowledgements}

This work was supported by a grant from the Rigshospitalet Research Council to LP. Supplementary material

Supplementary material (forrest plots of all meta-analyses and an additional table on immunosuppressive treatment strategies and drug target levels of the included studies) is available at European Journal of Clinical Pharmacology online. 
Reference List

1. Taylor DO, Stehlik J, Edwards LB et al (2009) Registry of the international society for heart and lung transplantation: twenty-sixth official adult heart transplant report-2009. J.Heart Lung Transplant 28:1007-1022.

2. Valantine $H(2000)$ Neoral use in the cardiac transplant recipient. Transplant Proc. 32:27S$44 \mathrm{~S}$.

3. Kapturczak MH, Meier-Kriesche HU, Kaplan B (2004) Pharmacology of calcineurin antagonists. Transplant Proc. 36:25S-32S.

4. Starzl TE, Todo S, Fung J, Demetris AJ, Venkataramman R, Jain A (1989) FK 506 for liver, kidney, and pancreas transplantation. Lancet 2:1000-1004.

5. McCormack PL, Keating GM (2006) Tacrolimus: in heart transplant recipients. Drugs 66:2269-2279.

6. Banner NR (2006) Tacrolimus: In heart transplant recipients - A viewpoint by Nicholas R. Banner. Drugs 66:2280-2282.

7. Higgins, J. P. and Green, S.Cochrane Handbook for Systematic Reviews of Interventions Version 5.0.2 [updated September 2009]. The Cochrane Collaboration, 2009. Available from www.cochrane-handbook.org.

Ref Type: Generic

8. Moher D, Liberati A, Tetzlaff J, Altman DG (2009) Preferred reporting items for systematic reviews and meta-analyses: the PRISMA statement. J.Clin.Epidemiol. 62:1006-1012.

9. Stewart S, Winters GL, Fishbein MC et al (2005) Revision of the 1990 working formulation for the standardization of nomenclature in the diagnosis of heart rejection. J.Heart Lung Transplant 24:1710-1720.

10. Royle P, Waugh N (2003) Literature searching for clinical and cost-effectiveness studies used in health technology assessment reports carried out for the National Institute for Clinical Excellence appraisal system. Health Technol.Assess. 7:iii, ix-51.

11. Schulz KF, Chalmers I, Hayes RJ, Altman DG (1995) Empirical evidence of bias. Dimensions of methodological quality associated with estimates of treatment effects in controlled trials. JAMA 273:408-412.

12. Higgins JP, Thompson SG (2002) Quantifying heterogeneity in a meta-analysis. Stat.Med. 21:1539-1558.

13. Altman DG, Bland JM (2003) Interaction revisited: the difference between two estimates. BMJ 326:219. 
14. Wetterslev J, Thorlund K, Brok J, Gluud C (2008) Trial sequential analysis may establish when firm evidence is reached in cumulative meta-analysis. J.Clin.Epidemiol. 61:64-75.

15. Grimm M, Rinaldi M, Yonan NA et al (2006) Superior prevention of acute rejection by tacrolimus vs. cyclosporine in heart transplant recipients - A large European trial. Am J Transplant 6:1387-1397.

16. Kobashigawa J, Patel J, Furukawa H et al (2006) Five-year results of a randomized, singlecenter study of tacrolimus vs microemulsion cyclosporine in heart transplant patients. J.Heart Lung Transplant 25:434-439.

17. Kobashigawa JA, Miller LW, Russell SD (2004) A randomized, prospective, multicenter comparison of tacrolimus, mycopholate mofetil (mmf) and steroids vs cyclosporine microemulsion, mmf and steroids vs tacrolimus, sirolimus and steroids in de novo cardiac transplantation recipients - 6 month report. 3rd Int Congr Immunosuppr; 2004, San.Diego.

18. Kobashigawa JA, Patel JK, Furukawa H, Marquez A, Oeser BT, Laks H (2004) Five-year results of a randomized single center study of tacrolimus versus microemulsion cyclosporine in heart transplant patients. 3rd Int Congr Immunosuppr; 2004; San.Diego.

19. Kobashigawa JA, Miller LW, Russell SD et al (2006) Tacrolimus with mycophenolate mofetil (MMF) or sirolimus vs. Cyclosporine with MMF in cardiac transplant patients: 1year report. Am J Transplant 6:1377-1386.

20. Meiser BM, Groetzner J, Kaczmarek I et al (2004) Tacrolimus or cyclosporine: Which is the better partner for mycophenolate-mofetil in heart transplant recipients? Transplantation 78:591-598.

21. Meiser BM, Scheersoi T, Pfeiffer M et al (2000) Comparison of trough level adjusted MMF application in combination with either Cyclosporine or Tacrolimus in a randomized study after heart transplantation. Transplantation 69:695.

22. Meiser BM, Uberfuhr P, Fuchs A et al (1996) Comparison between Tacrolimus (FK506) and Cyclosporin A (CyA) after heart transplantation: A randomised, controlled clinical study. Zeitschr Kardiol 85 Suppl 2:133.

23. Meiser BM, Uberfuhr P, Fuchs A et al (1998) Single-center randomized trial comparing tacrolimus (FK506) and cyclosporine in the prevention of acute myocardial rejection. $\mathrm{J}$ Heart Lung Transplant 17:782-788.

24. Reichart B, Meiser B, Vigano M et al (1998) European multicenter tacrolimus (FK506) heart pilot study: One-year results-European tacrolimus multicenter heart study group. $\mathbf{J}$ Heart Lung Transplant 17:1998.

25. Pollock-BarZiv SMD, Dipchand AI, McCrindle BW, Nalli N, West LJ (2005) Randomized clinical trial of tacrolimus- vs cyclosporine-based immunosuppression in pediatric heart transplantation: Preliminary results at 15-month follow-up. J Heart Lung Transplant 24:Feb. 
26. Rinaldi M, Pellegrini C, Martinelli L et al (1997) FK506 effectiveness in reducing acute rejection after heart transplantation: a prospective randomized study. J.Heart Lung Transplant 16:1001-1010.

27. Taylor DO, Barr ML, Radovancevic B et al (1999) A randomized, multicenter comparison of tacrolimus and cyclosporine immunosuppressive regimens in cardiac transplantation: decreased hyperlipidemia and hypertension with tacrolimus. The Journal of heart and lung transplantation : the official.publication.of the International Society for.Heart Transplantation 18:336-345.

28. Wang CH, Ko WJ, Chou N, Wang SS (2004) Efficacy and safety of tacrolimus versus cyclosporine microemulsion in primary cardiac transplant recipients: 6-month results in Taiwan. Transplant Proc 36:2384-2385.

29. Wang CH, Ko WJ, Chou N, Wang SS (2004) Therapeutic drug monitoring of tacrolimus in cardiac transplant recipients: A comparison with cyclosporine neoral. Transplant Proc $36: 2386-2387$.

30. Wang SS, Chou NK, Chi NH et al (2008) Heart transplantation under cyclosporine or tacrolimus combined with mycophenolate mofetil or everolimus. Transplant Proc 40:26072608 .

31. Groetzner J, Meiser BM, Schirmer J et al (2001) Tacrolimus or cyclosporine for immunosuppression after cardiac transplantation: which treatment reveals more side effects during long-term follow-up? Transplant Proc 33:1461-1464.

32. Groetzner J, Meiser B, Schirmer J et al (2001) Tacrolimus/Mycophenolate mofetil vs Cyclosporine/Mycophenolate mofetil: Comparison of Mycophenolate mofetil acid trough levels and coronary vasomotor function. J Heart Lung Transplant 20:191.

33. Groetzner J, Meiser B, Schirmer J et al (2002) Tacrolimus/Mycophenolate Mofetil vs Cyclosporine/Mycophenolate Mofetil: Impact on infections following cardiac transplantation. J Heart Lung Transplant 21:120.

34. Schirmer J, Meiser B, Kadner A et al (2001) Tacrolimus versus cyclosporine after HTX: Comparison of long-term effects. J Heart Lung Transplant 20:191.

35. Grimm M, Rinaldi M, Yonan NA (2003) Efficacy and safety of Tacrolimus (TAC) vs. Cyclosporine microemulsion (CME) in de novo cardiac transplant recipients: 6-month results. J Heart Lung TransplantS92.

36. Taylor DO, Barr ML, Radovancevic B et al (1997) A comparison of tacrolimus- and cyclosporine-based immunosuppression in cardiac transplantation. J Heart Lung Transplant 16.

37. Petrakopoulou P, Anthopoulou L, Muscholl M et al (2006) Coronary endothelial vasomotor function and vascular remodeling in heart transplant recipients randomized for tacrolimus or cyclosporine immunosuppression. JACC 47:1622-1629. 
38. Steinbüchel Nv, Limm H, Leopold C, Carr D (2000) Assessment of health-related qualityof-life in patients after heart transplantation under therapy with tacrolimus or cyclosporine. Transpl Int 13 Suppl 1:S609-S614.

39. Reichart B, Meiser B, Vigano $\mathrm{M}$ et al (2001) European multicenter tacrolimus heart pilot study: three year follow-up. J.Heart Lung Transplant. 20:249-250.

40. Gluud LL (2006) Bias in clinical intervention research. Am.J.Epidemiol. 163:493-501.

41. Eisen HJ, Hobbs RE, Davis SF et al (2001) Safety, tolerability, and efficacy of cyclosporine microemulsion in heart transplant recipients: a randomized, multicenter, double-blind comparison with the oil-based formulation of cyclosporine--results at 24 months after transplantation. Transplantation 71:70-78.

42. Podesser BK, Rinaldi M, Yona NA et al (2005) Comparison of low and high initial tacrolimus dosing in primary heart transplant recipients: A prospective European multicenter study. Transplantation 79:65-71.

43. Cantarovich M, Barkun J, Giannetti N, Cecere R, Besner JG, Tchervenkov J (2004) History of $\mathrm{C} 2$ monitoring in heart and liver transplant patients treated with cyclosporine microemulsion. Transplant Proc. 36:442S-447S.

44. Iversen M, Nilsson F, Sipponen J et al (2009) Cyclosporine C2 levels have impact on incidence of rejection in de novo lung but not heart transplant recipients: the NOCTURNE study. J.Heart Lung Transplant 28:919-926.

45. Fan Y, Xiao YB, Weng YG, Hetzer R (2009) Tacrolimus Versus Cyclosporine Microemulsion for Heart Transplant Recipients: A Meta-analysis. J Heart Lung Transplant 28:58-66.

46. Mehra MR, Uber PA, Park MH, Prasad AK, Scott RL (2001) A randomized comparison of an immunosuppressive strategy using tacrolimus and cyclosporine in black heart transplant recipients. Transplant Proc 33:1606-1607.

47. McAlister VC, Haddad E, Renouf E, Malthaner RA, Kjaer MS, Gluud LL (2006) Cyclosporin versus tacrolimus as primary immunosuppressant after liver transplantation: a meta-analysis. Am.J.Transplant 6:1578-1585.

48. Webster AC, Woodroffe RC, Taylor RS, Chapman JR, Craig JC (2005) Tacrolimus versus ciclosporin as primary immunosuppression for kidney transplant recipients: meta-analysis and meta-regression of randomised trial data. BMJ 331:810-821. 
Table 1. Characteristics of included trials.

\begin{tabular}{|l|l|l|l|l|l|}
\hline Trial & $\begin{array}{l}\text { Number } \\
\text { of patients }\end{array}$ & $\begin{array}{l}\text { Age }(\text { Y }) \\
\text { Tac/Cyclo }\end{array}$ & $\begin{array}{l}\text { Follow- } \\
\text { up period } \\
(\text { mo })\end{array}$ & $\begin{array}{l}\text { Adult/ } \\
\text { Paediat } \\
\text { ric }\end{array}$ & $\begin{array}{l}\text { Oil-based/micro- } \\
\text { emulsion } \\
\text { Cyclosporine }\end{array}$ \\
\hline Rinaldi 1997 & 25 & $49 / 53$ & 12 & A & Oil-based \\
\hline Reichart 1998 & 82 & $50 / 52$ & 36 & A & Oil-based \\
\hline Taylor 1999 & 85 & $53 / 53$ & 12 & A & Oil-based \\
\hline Meiser 2004 & 60 & $55 / 55$ & 24 & A & Micro emulsion \\
\hline Wang 2004 & 21 & $49 / 44$ & 6 & A & Micro emulsion \\
\hline $\begin{array}{l}\text { Pollock- } \\
\text { BarZiv 2005 }\end{array}$ & 26 & $4 / 5$ & 26 & $\mathrm{P}$ & Micro emulsion \\
\hline Grimm 2006 & 314 & $51 / 51$ & 18 & A & Micro emulsion \\
\hline $\begin{array}{l}\text { Kobashigawa } \\
\text { 2006 A }\end{array}$ & 67 & $34 / 28$ & 60 & A/P & Micro emulsion \\
\hline $\begin{array}{l}\text { Kobashigawa } \\
\text { 2006 B }\end{array}$ & 223 & $54 / 51$ & 12 & A & Micro emulsion \\
\hline Wang 2008 & 49 & $\begin{array}{l}\text { Un } \\
\text { known }\end{array}$ & 36 & A & Micro emulsion \\
\hline
\end{tabular}


Table 2 Assessment of methodology quality

\begin{tabular}{|l|l|l|l|l|l|}
\hline Trial & Allocation & Allocation & Blinding & Intention & Incomplete outcome \\
& sequence & concealment & & to treat & data addressed \\
\hline Rinaldi 1997 & Unclear & Unclear & No - only biopsies & Yes & Yes \\
\hline Reichart 1998 & Adequate & Adequate & No & Yes & Yes \\
\hline Taylor 1999 & Unclear & Adequate & No - only biopsies & Unclear & Unclear \\
\hline Meiser 2004 & Unclear & Unclear & No & Yes & Yes \\
\hline Wang 2004 & Unclear & Unclear & No & Yes & Unclear \\
\hline Pollock-BarZiv & Unclear & Unclear & No - only biopsies & Yes & Yes \\
\hline Grimm 2006 & Adequate & Adequate & No - only biopsies & Yes & Yes \\
\hline Kobashigawa & Unclear & Unclear & No -only biopsies and & Yes & Yes \\
\hline 2006 A & & & coronary angiography & & \\
\hline Kobashigawa & Unclear & Unclear & Unclear & Yes & Yes \\
\hline Wang 2008 & Unclear & Unclear & No & Yes & Yes \\
\hline
\end{tabular}


Figure legends

Figure 1. Diagram of identification of randomized trials for inclusion

Figure 2. Intervention effect of tacrolimus vs. cyclosporine on mortality

Figure 3. Intervention effect of tacrolimus vs. cyclosporine on biopsy proven acute rejection $\geq 3 \mathrm{a}$

Figure 4. Intervention effect of tacrolimus vs. cyclosporine on hypertension

Figure 5. Intervention effect of tacrolimus vs. cyclosporine on hyperlipidaemia requiring treatment

Figure 6. Intervention effect of tacrolimus vs. cyclosporine on post-transplant diabetes

Figure legends to supplementary electronic material

Figure 7. Intervention effect of tacrolimus vs. cyclosporine on rejection causing hemodynamic instability

Figure 8. Intervention effect of tacrolimus vs. cyclosporine on infection rate

Figure 9. Intervention effect of tacrolimus vs. cyclosporine on CMV-infection rate

Figure 10. Intervention effect of tacrolimus vs. cyclosporine on malignancy

Figure 11. Intervention effect of tacrolimus vs. cyclosporine on basocellular skin cancer

Figure 12. Intervention effect of tacrolimus vs. cyclosporine on renalfailure requiring haemodialysis

Figure 13. Intervention effect of tacrolimus vs. cyclosporine on serum creatinine ( $\mu \mathrm{mol} / \mathrm{L})$

Figure 14. Intervention effect of tacrolimus vs. cyclosporine on chronic allograft vasculopathy

Figure 15. Intervention effect of tacrolimus vs. cyclosporine on hirsutism

Figure 16. Intervention effect of tacrolimus vs. cyclosporine on gingival hyperplasia

Figure 17. Intervention effect of tacrolimus vs. cyclosporine on neurotoxicity 
Figure 18. Intervention effect of tacrolimus vs. cyclosporine on total blood cholesterol (mmol/L)

\begin{tabular}{|c|c|c|c|c|c|}
\hline Trial & $\begin{array}{l}\text { Type of } \\
\text { cyclosporine }\end{array}$ & $\begin{array}{l}\text { Cyclosporine } \\
\text { trough } \\
\text { target/dose }\end{array}$ & $\begin{array}{l}\text { Tacrolimus dose } \\
\text { (mg/ } \mathrm{kg} / \mathrm{d}) / \\
\text { Target }(\mathrm{ng} / \mathrm{dl})\end{array}$ & $\begin{array}{l}\text { Azathioprine } \\
\text { /MMF dose }\end{array}$ & Inductiontherapy \\
\hline Rinaldi 1997 & Oil-based & $\begin{array}{l}\text { 0-1 mo: } 180-360 \\
>1 \mathrm{mo}: 80-180 \\
(2-6 \mathrm{mg} / \mathrm{kg} / \mathrm{d})\end{array}$ & $\begin{array}{l}0-12: 15-25(0.15 \\
\mathrm{mg} / \mathrm{kg} / \mathrm{d}) \\
\text { Reduced during study }\end{array}$ & $\begin{array}{l}\text { Azathioprine: } \\
\text { Pre-operat: } \\
4 \mathrm{mg} / \mathrm{kg} \\
\text { Maintenance: } 1-2 \\
\mathrm{mg} / \mathrm{kg}\end{array}$ & Yes, Rabbit ATG \\
\hline $\begin{array}{l}\text { Reichart } \\
1998\end{array}$ & Oil-based & $\begin{array}{l}\text { 0-6 mo: } 200-400 \\
>6 \text { mo: } 150-250\end{array}$ & $\begin{array}{l}0-28 \mathrm{~d}: 15-25(0.3 \\
\mathrm{mg} / \mathrm{kg} / \mathrm{d} ; \\
>28 \mathrm{~d}: 10-20 \\
\text { Later adjusted to } 0-12 \\
\mathrm{mo:}<15(<0.3 \\
\mathrm{mg} / \mathrm{kg} / \mathrm{d}\end{array}$ & $\begin{array}{l}\text { Azathioprine: } \\
210+/-147 \\
\text { Cum. Dosis } \\
\text { (Tacrolimus treatm } \\
\text { gr.) } \\
324+/-125 \\
\text { Cum. Dosis } \\
\text { (Ciclosporin treatm } \\
\text { gr.) }\end{array}$ & Partly, ATG \\
\hline Taylor 1999 & Oil-based & $\begin{array}{l}0-1 \mathrm{mo}: 250-600 \\
1-3 \mathrm{mo}: 200-400 \\
>3 \mathrm{mo}: 150-250\end{array}$ & $\begin{array}{l}\text { 0-1 mo: } 10-20 \\
\text { 1-3 mo: } 10-15 \\
>3 \text { mo: } 5-10\end{array}$ & $\begin{array}{l}\text { Azathioprine: } \\
\text { Pre-operat: } \\
4 \mathrm{mg} / \mathrm{kg} \\
\text { Maintenance: } 2 \mathrm{mg} / \mathrm{kg}\end{array}$ & $\begin{array}{l}\text { Partly, OKT3 in } \\
\text { high-risk patients }\end{array}$ \\
\hline Meiser 2004 & $\begin{array}{l}\text { Micro } \\
\text { emulsion }\end{array}$ & $\begin{array}{l}\text { 0-6 mo: } 200-300 \\
>6 \text { mo: } 100-200\end{array}$ & $\begin{array}{l}\text { 0-6 mo: } 13-15 \\
>6 \text { mo: } 10-12\end{array}$ & $\begin{array}{l}\text { MMF: } \\
0-6 \mathrm{mo}: 2.5-4 \mathrm{ug} / \mathrm{ml} \\
>3 \mathrm{mo}: 5-15\end{array}$ & No \\
\hline Wang 2004 & $\begin{array}{l}\text { Micro } \\
\text { emulsion }\end{array}$ & $\begin{array}{l}0-3 \mathrm{mo}: 300 \\
(6 \mathrm{mg} / \mathrm{kg} / \mathrm{d})\end{array}$ & $\begin{array}{l}\text { 0-3 mo: } 10-20(0.15 \\
\mathrm{mg} / \mathrm{kg} / \mathrm{d} ; \\
>3 \mathrm{mo}: 5-15\end{array}$ & Azathioprine & Yes, Rabbit ATG \\
\hline $\begin{array}{l}\text { Pollock- } \\
\text { BarZiv } 2005\end{array}$ & $\begin{array}{l}\text { Micro } \\
\text { emulsion }\end{array}$ & $\begin{array}{l}0-6 \mathrm{mo}: 250-325 \\
(6-10 \mathrm{mg} / \mathrm{kg} / \mathrm{d}) \\
>6 \mathrm{mo}: 200-250\end{array}$ & $\begin{array}{l}0-6 \mathrm{mo}: 10-12(0.1- \\
0.3 \mathrm{mg} / \mathrm{kg} / \mathrm{d} ; \\
>6 \mathrm{mo}: 8-10\end{array}$ & $\begin{array}{l}\text { Azathioprine } \\
2-3 \mathrm{mg} / \mathrm{kg} / \mathrm{d} \text {; }\end{array}$ & $\begin{array}{l}\text { Yes, Polyclonal } \\
\text { Rabbit ATG }\end{array}$ \\
\hline Grimm 2006 & $\begin{array}{l}\text { Micro } \\
\text { emulsion }\end{array}$ & $\begin{array}{l}\text { 1-3 mo: } 200-350 \\
>3 \mathrm{mo}: 100-200\end{array}$ & $\begin{array}{l}\text { 1-3 mo: } 10-20 \\
>3 \text { mo: } 5-15\end{array}$ & $\begin{array}{l}\text { Azathioprine } \\
2-4 \mathrm{mg} / \mathrm{kg} / \mathrm{d} ; \\
\text { WBC>2000 cells/ul }\end{array}$ & Yes, ATG or OKT3 \\
\hline $\begin{array}{l}\text { Kobashigawa } \\
2006 \text { A }\end{array}$ & $\begin{array}{l}\text { Micro } \\
\text { emulsion }\end{array}$ & $\begin{array}{l}\text { 0-1 mo: } 250-350 ; \\
>1 \mathrm{mo}: 150-250\end{array}$ & $\begin{array}{l}\text { 0-1 mo: } 10-15 \\
>1 \mathrm{mo}: 5-10\end{array}$ & $\begin{array}{l}\text { Azathioprine } 2 \\
\mathrm{mg} / \mathrm{kg} / \mathrm{d} ; \text { WBC }>3500 \\
\text { cells/ul }\end{array}$ & No \\
\hline $\begin{array}{l}\text { Kobashigawa } \\
2006 \text { B }\end{array}$ & $\begin{array}{l}\text { Micro } \\
\text { emulsion }\end{array}$ & $\begin{array}{l}\text { 0-3 mo: } 200-400 \\
>3 \mathrm{mo}: 100-300\end{array}$ & $\begin{array}{l}\text { 0-3 mo: } 10-20 \\
\text { >3 mo: } 5-15\end{array}$ & $\begin{array}{l}\text { MMF: } \\
\text { Start } 3 \mathrm{~g} / \mathrm{d} \\
\text { Target whole blood } \\
\text { trough conc } 3-5 \\
\mathrm{ng} / \mathrm{mL}\end{array}$ & $\begin{array}{l}\text { Partly, ATGAM, } \\
\text { OKT3 or RATG } \\
\text { allowed, and only } \\
\text { encouraged with } \\
\text { renal dysfunction }\end{array}$ \\
\hline Wang 2008 & $\begin{array}{l}\text { Micro } \\
\text { emulsion }\end{array}$ & Unknown & Unknown & MMF & Yes, type unknown \\
\hline
\end{tabular}

\section{Supplementary material:}

Table 3 Immunosuppressive treatment strategies of included trials 


\section{Potentiallly relevant references CENTRAL: $\quad 76$ \\ Medline: $\quad 117$ \\ Embase: $\quad 126$ \\ Web of Science: 136 \\ Other: \\ 8}

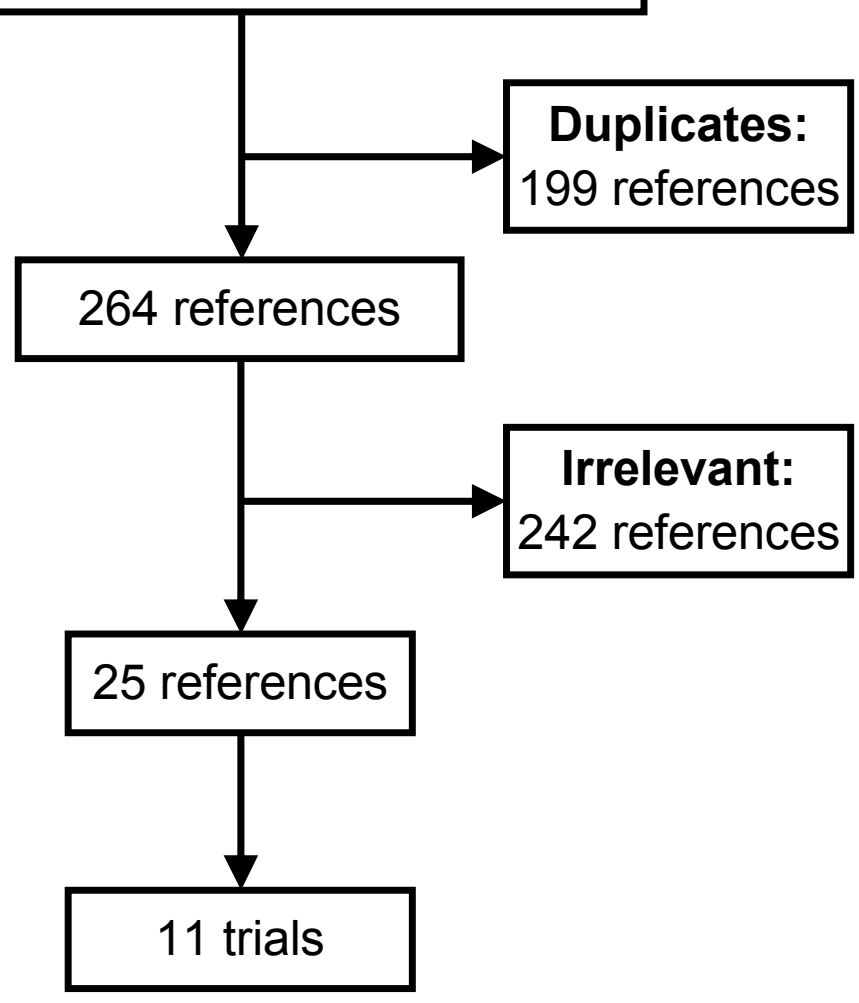


Intervention effect of tacrolimus vs. cyclosporine on mortality $64 \times 39 \mathrm{~mm}(300 \times 300 \mathrm{DPI})$ 
Intervention effect of tacrolimus vs. cyclosporine on biopsy proven acute rejection $\geq 3 a$ $64 \times 32 \mathrm{~mm}(300 \times 300 \mathrm{DPI})$ 
Intervention effect of tacrolimus vs. cyclosporine on hypertension $64 \times 36 \mathrm{~mm}(300 \times 300 \mathrm{DPI})$ 
Intervention effect of tacrolimus vs. cyclosporine on hyperlipidaemia requiring treatment $63 \times 31 \mathrm{~mm}(300 \times 300$ DPI $)$ 
Intervention effect of tacrolimus vs. cyclosporine on post-transplant diabetes $64 \times 36 \mathrm{~mm}(300 \times 300$ DPI $)$ 


\section{European Journal of Clinical Pharmacology}

Intervention effect of tacrolimus vs. cyclosporine on rejection causing hemodynamic instability $64 \times 32 \mathrm{~mm}(300 \times 300 \mathrm{DPI})$ 
2

3

4

5

6

7

8

9

10

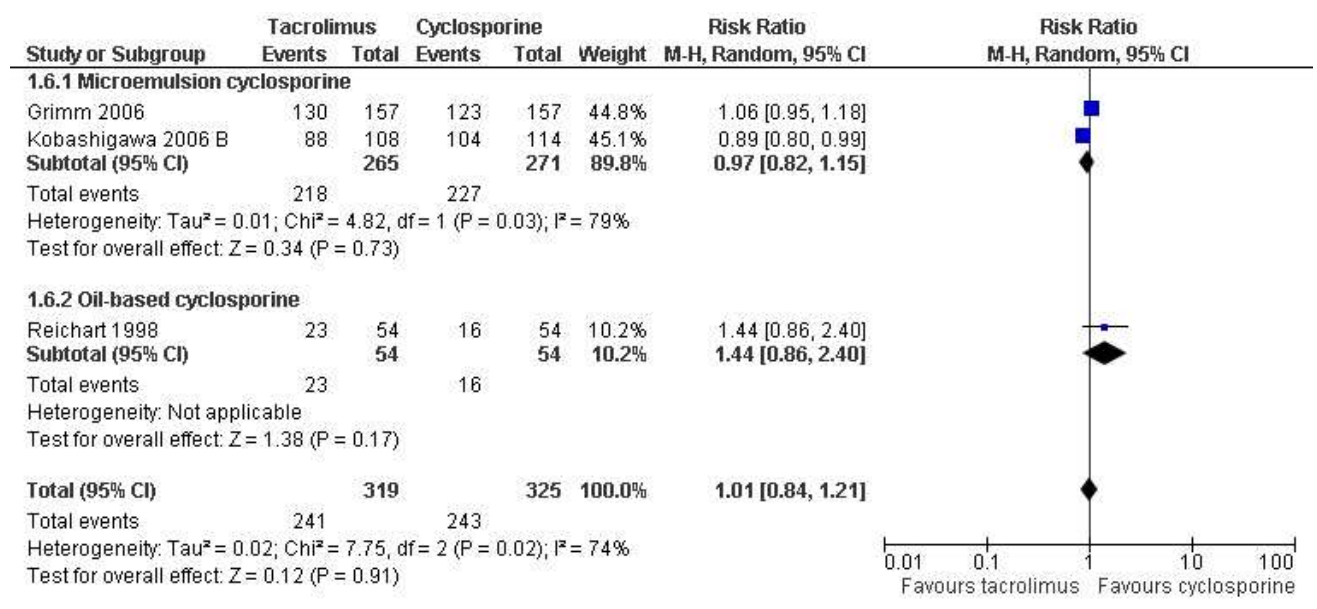

Intervention effect of tacrolimus vs. cyclosporine on infection rate $64 \times 29 \mathrm{~mm}(300 \times 300 \mathrm{DPI})$ 


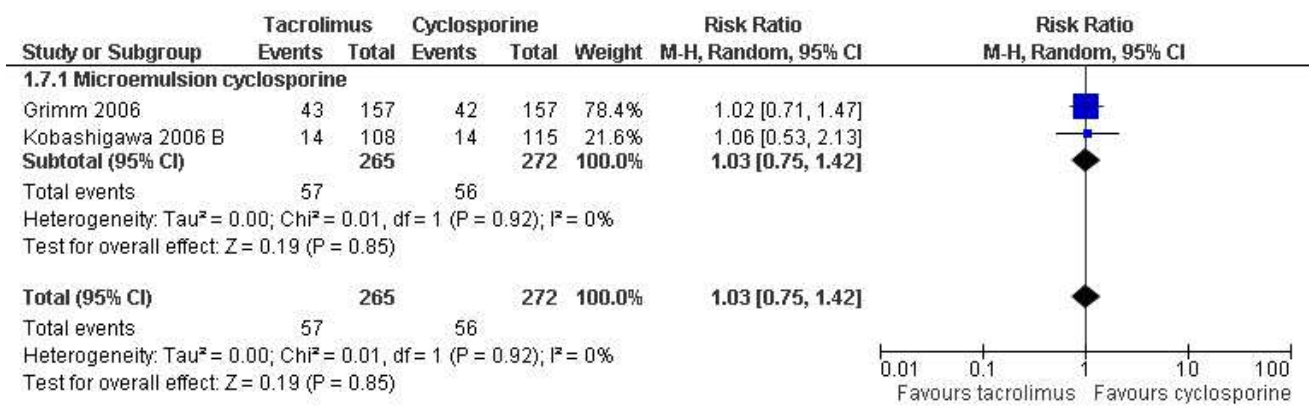

Intervention effect of tacrolimus vs. cyclosporine on CMV-infection rate $64 \times 20 \mathrm{~mm}(300 \times 300 \mathrm{DPI})$ 


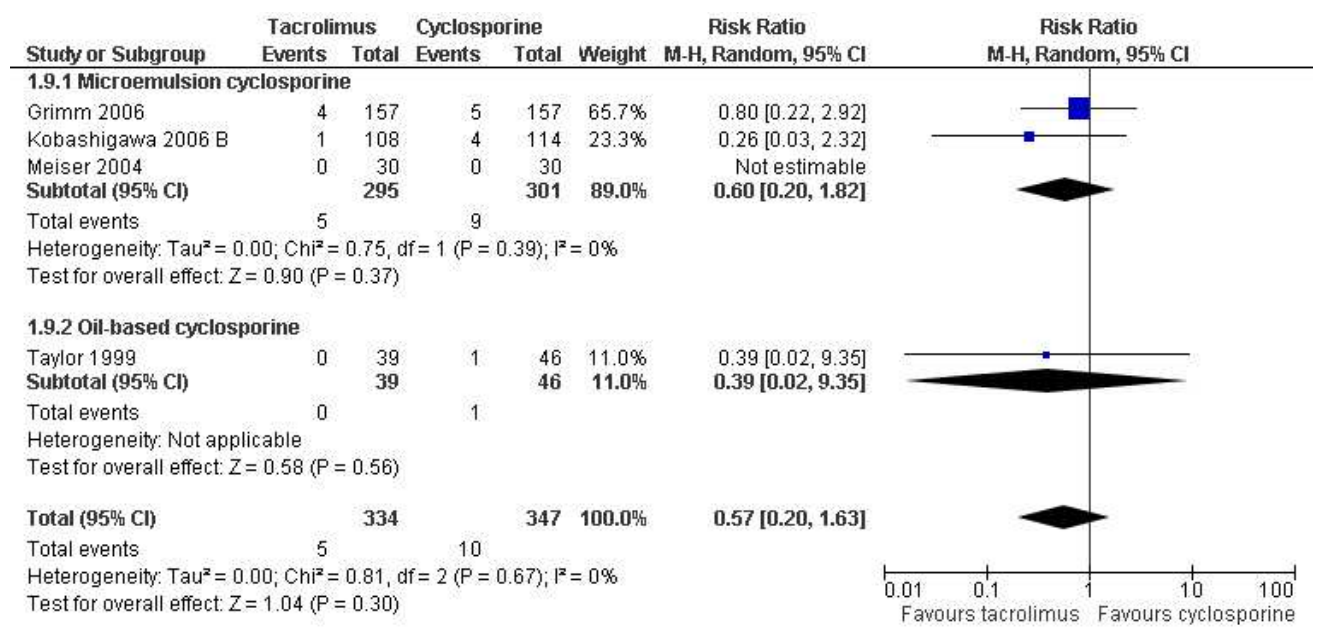

Intervention effect of tacrolimus vs. cyclosporine on malignancy $64 \times 31 \mathrm{~mm}(300 \times 300 \mathrm{DPI})$ 


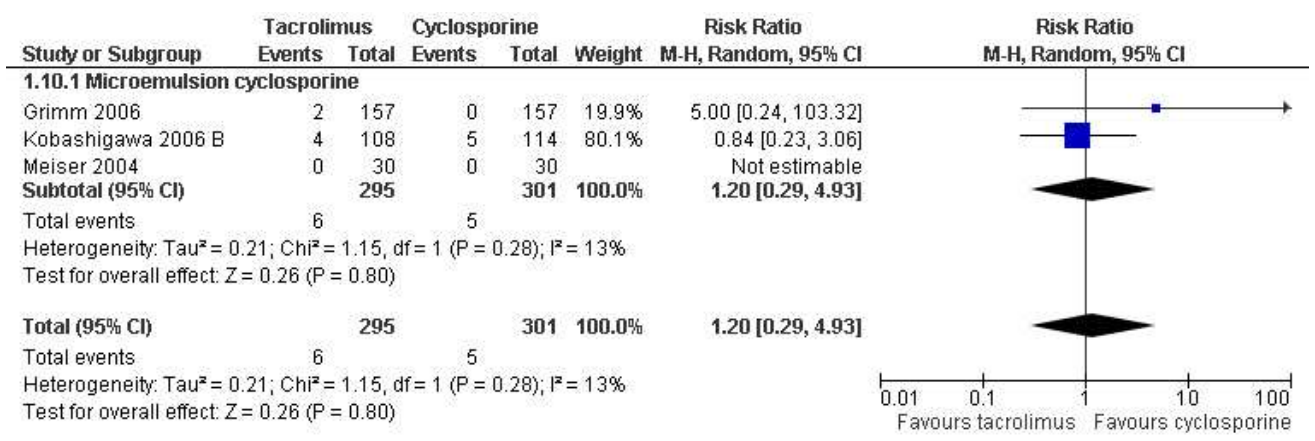

Intervention effect of tacrolimus vs. cyclosporine on basocellular skin cancer $64 \times 21 \mathrm{~mm}(300 \times 300 \mathrm{DPI})$ 


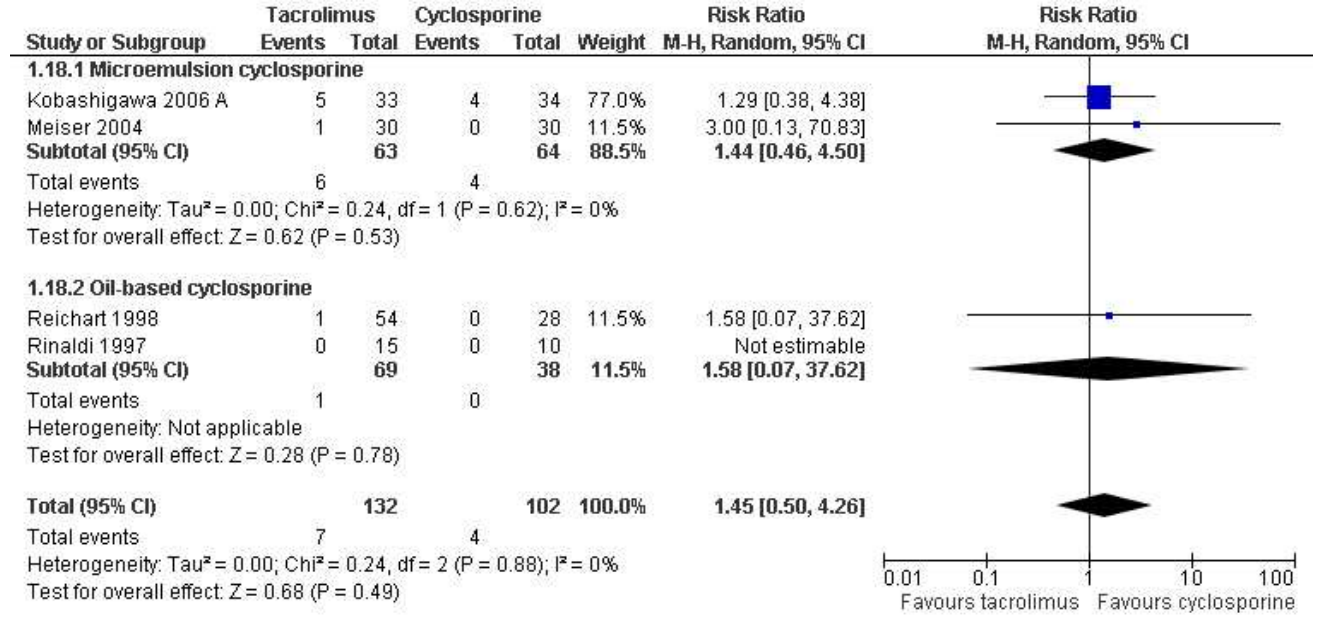

Intervention effect of tacrolimus vs. cyclosporine on renalfailure requiring haemodialysis $64 \times 31 \mathrm{~mm}(300 \times 300 \mathrm{DPI})$ 


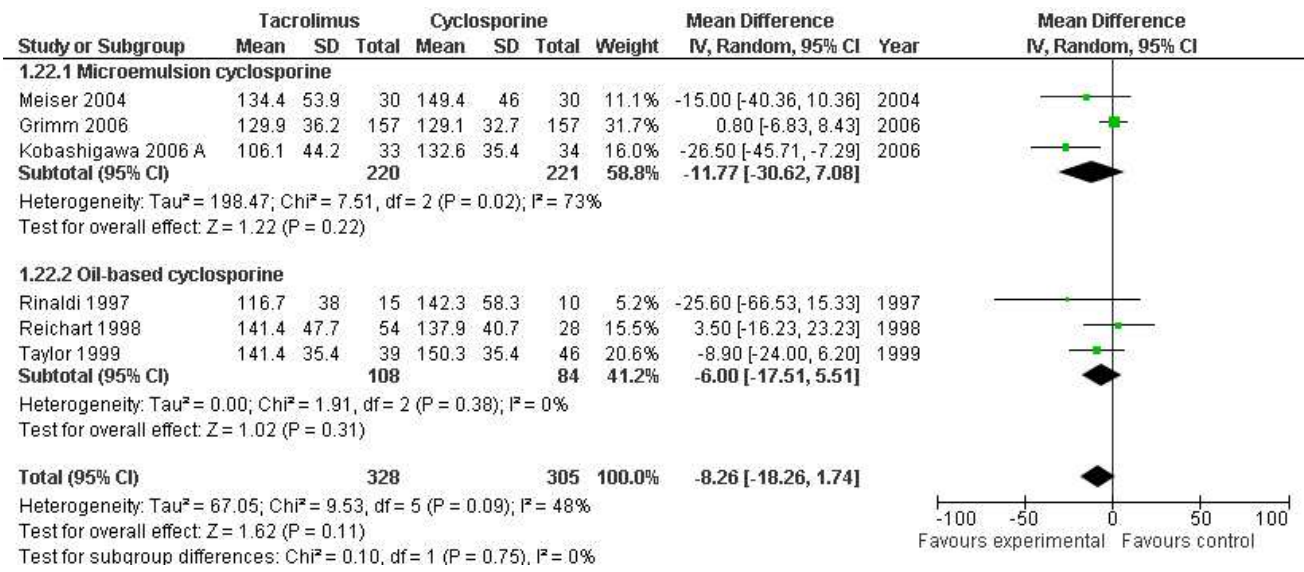

Intervention effect of tacrolimus vs. cyclosporine on serum creatinine ( $\mu \mathrm{mol} / \mathrm{L})$ $69 \times 29 \mathrm{~mm}(300 \times 300 \mathrm{DPI})$ 


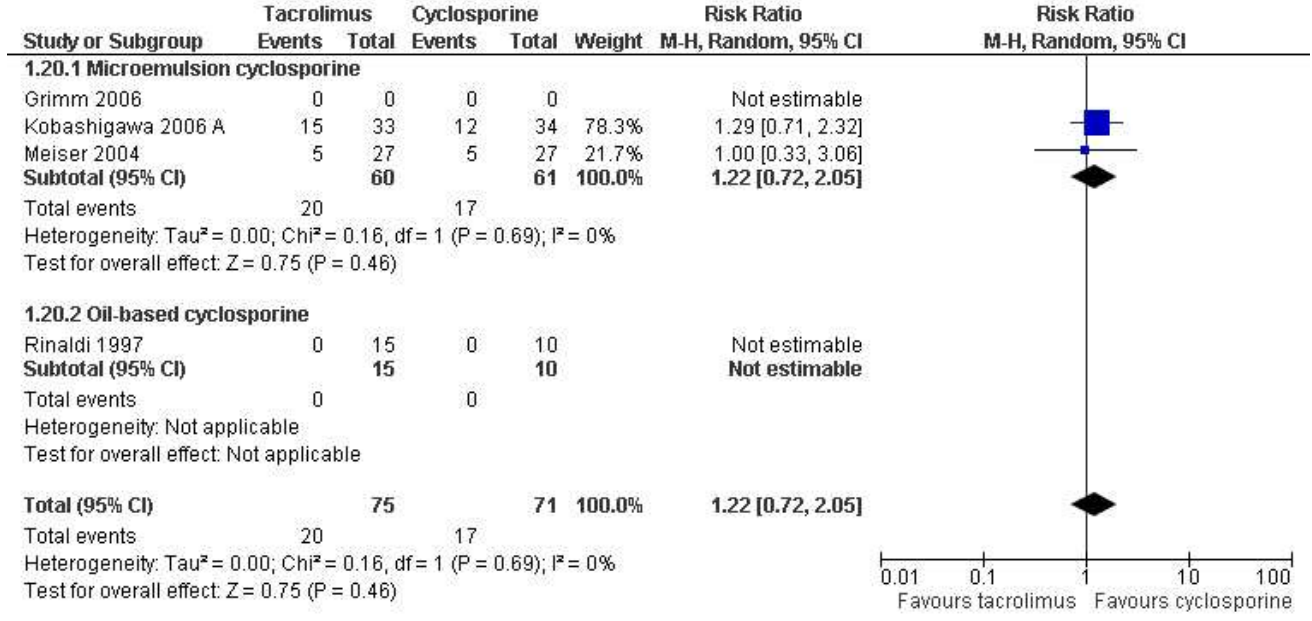

Intervention effect of tacrolimus vs. cyclosporine on chronic allograft vasculopathy $64 \times 31 \mathrm{~mm}(300 \times 300 \mathrm{DPI})$ 


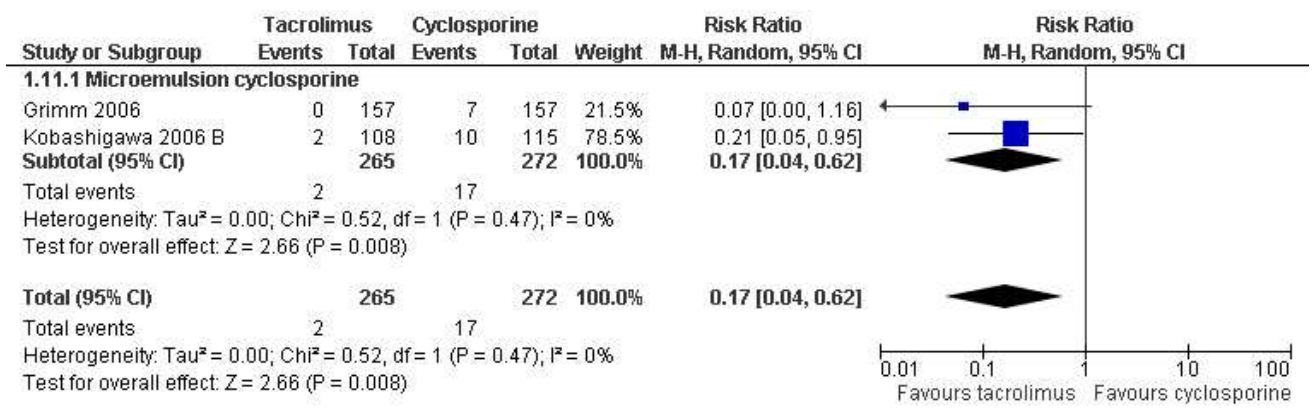

Intervention effect of tacrolimus vs. cyclosporine on hirsutism $64 \times 20 \mathrm{~mm}(300 \times 300$ DPI $)$ 
Intervention effect of tacrolimus vs. cyclosporine on gingival hyperplasia $64 \times 21 \mathrm{~mm}(300 \times 300$ DPI $)$ 
Intervention effect of tacrolimus vs. cyclosporine on neurotoxicity $64 \times 32 \mathrm{~mm}(300 \times 300 \mathrm{DPI})$ 


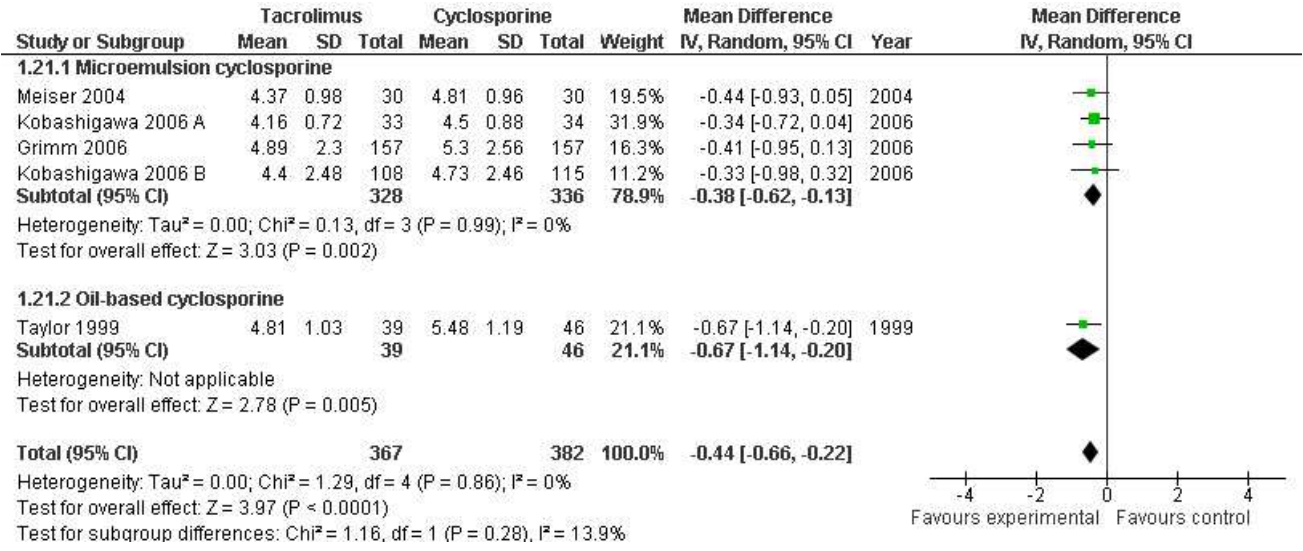

Intervention effect of tacrolimus vs. cyclosporine on total blood cholesterol ( $\mathrm{mmol} / \mathrm{L})$ $68 \times 28 \mathrm{~mm}(300 \times 300 \mathrm{DPI})$ 